\title{
Structural framework of rocks of the Lagoa D’anta mine area, iron-manganese Urandi- Caetité-Licínio de Almeida District, Bahia, Brasil
}

\author{
Arcabouço estrutural das rochas da mina Lagoa D'anta, distrito \\ ferro-manganesífero Urandi-Caetité-Licínio de Almeida, Bahia, Brasil \\ Jofre de Oliveira Borges ${ }^{1 *}$, Simone Cerqueira Pereira Cruz ${ }^{1}$, \\ Johildo Salomão Figueiredo Barbosa ${ }^{1}$, Edmar da Silva Santos ${ }^{2}$
}

\begin{abstract}
The Urandi-Caetité-Licínio de Almeida Iron-Manganese District encompasses a total of 35 manganese mines, most of which are already exhausted, and 1 currently active iron mine. The host rocks of these ores are associated with the Paleoproterozoic Caetité-Licínio de Almeida Metavolcanossedimentary Sequence. These units have been deformed by the northern Serra do Espinhaço Thrust and Fold Belt, in the northern section of the Araçuaí Orogen. Interbeddings of itabirite, cummingtonite schist, calcite and manganese-dolomitic marbles, calc-silicate and carbonate-silicate rocks, and amphibolitic metabasalt were found at the Lagoa D'anta mine, in addition to quartz-jacobsite schist, residual manganese-rich soil and manganese lateritic breccia. The main structural framework presents a general NE-SW trend and it consists predominantly of compressional structures. This structural framework is associated with the evolution of two Ediacaran dextral transpressional shear zones, the Carrapato zone, in the western portion, and São Timóteo zone, in the eastern portion. The structural framework of the Lagoa D'anta mine reflects a higher degree of shortening in the southern sector of the northern Serra do Espinhaço Thrust and Fold Belt, in the northern area of the Araçuaí Orogen. The ductile structures related to these deformational phases were nucleated under conditions of progressive metamorphism with minimum temperature of $550^{\circ} \mathrm{C}$. Stockwork structures of quartz, calcite, epidote, grunerite and magnetite truncate the mine's ductile structures. Fractures were the main circulation channels for meteoric water, which culminated in the formation of a high-content supergene ore in the mine.
\end{abstract}

KEYWORDS: structural framework; aulacogen; shear zones; deformation.
RESUMO: O Distrito Ferro-Manganesifero Urandi-Caetité-Licinio de Almeida congrega um total de 35 minas de manganês, a maioria exaurida, e 1 mina de ferro, em atividade, cujas rochas hospedeiras dos minérios estão associadas com a Sequência MetavulcanossedimentarCaetité-Licinio de Almeida, de idade paleoproterozoica. Essas unidades encontram-se deformadas pelo Cinturão de Dobramentos e Cavalgamentos Serra do Espinhaço setentrional, na porção norte do Orógeno Araçuai. Na mina Lagoa D’anta, foram identificadas intercalaçōes de itabirito, cummingtonita xistos, mármore calcitico e manganodolomitico, rochas calcissilicáticas e carbonato-silicáticas, metabasalto anfibolítico, além de quartzo-jacobsita xisto, solo residual rico em manganês e brecha lateritica manganesifera. O arcabouço estrutural principal apresenta trend geral NE-SW, sendo constituido dominantemente por estruturas compressionais. Esse arcabouço está associado com a evoluçáo de duas zonas de cisalhamento transpressionais destrais, de idade ediacarana, denominadas de Carrapato, a oeste, e São Timóteo, a leste. O arcabouço estrutural na mina Lagoa D'anta reflete um maior grau de encurtamento no setor sul do Cinturão de Dobramentos e Cavalgamentos Serra do Espinhaço setentrional, na porção norte do Orógeno Araçuaí. As estruturas dúcteis relacionadas com essas fases deformacionais foram geradas em condiçôes de metamorfismo progressivo com temperatura minima de $550^{\circ} \mathrm{C}$. Estruturas stockwork de quartzo, calcita, epidoto, grunerita e magnetita truncam as estruturas dúcteis da mina. Fraturas foram os principais canais de circulação de água meteórica que culminou com a formação de um minério supergênico de alto teor na mina.

PALAVRAS-CHAVE: arcabouço estrutural; aulacógeno; zonas de cisalhamento; deformação.

${ }^{1}$ Programa de Pesquisa e Pós-Graduação em Geologia, Instituto de Geociências, Departamento de Geologia, Universidade Federal da Bahia - UFBA, Salvador (BA), Brazil.E-mail:falecomjofre@gmail.com; simonecruzufba@gmail.com; johildo.barbosa@gmail.com

${ }^{2}$ Instituto de Geociências, Universidade Federal da Bahia - UFBA, Salvador (BA), Brazil. E-mail: edm.geo@gmail.com

*Corresponding author

Manuscript ID: 30183. Received: 10/14/2014. Approved: 03/26/2015. 


\section{INTRODUCTION}

The Lagoa D'anta mine is tectonically positioned in the Serra do Espinhaço Setentrional Thrust and Fold Belt (Figs. 1 and 2), in the northern sector of the Araçuaí Orogen. In its southern sector, this belt presents structural elements that reflect the inversion of the Paramirim Aulacogen (sensu Pedrosa-Soares et al. 2001) during the Ediacaran due to collisions between the São Francisco-Congo, Paranapanema, Rio de la Plata and Amazonian plates. These compressional deformations partially reworked structures older than $1.8 \mathrm{Ga}$ that were described in the basement of the aulacogen by Figueiredo (2009), Cruz et al. (2009, 2014), Medeiros (2012), and Figueiredo et al. (2013).

The Caetité-Licínio de Almeida Metavolcanossedimentary Sequence (Cunha et al. 2012), which has not been dated yet, though according to Cruz et al. (2014) it is likely to be a Paleoproterozoic sequence, is one of the units of the southern sector of the Serra do Espinhaço Setentrional Thrust and Fold Belt and of the basement of the Paramirim Aulacogen in the northern sector of the Araçuaí Orogen. This sequence hosts a total of 35 manganese mines (Fig. 3), most of which are already exhausted, and 1 iron mine, which is currently being exploited, comprising the Urandi-Caetité-Licínio de Almeida iron-manganese district (modified from Rocha et al. 1998). For manganese, the general predominating protore is the manganese-dolomite marble, with or without spessartite, and subordinately, quartz-jacobsite schist (Borges 2012). Regarding iron, lenticular bodies of pulverulent hematite schist predominate, which are intercalated by itabirite levels. These rocks underwent hydrothermal alteration mainly with magnetite enrichment and supergene alteration.

The first manganese discoveries in the Serra do Espinhaço Setentrional Thrust and Fold Belt were in 1948. The Lagoa D'anta mine was one of the most productive during the 1960's and 1970's. Despite the great advance of the mining fronts, this mine still represents an exuberant natural laboratory in which the rocks and deformational structures of the Caetité-Licínio de Almeida Metavolcanossedimentary Sequence are quite well-exposed.

The main objective of the present study was to present the structural framework of the Lagoa D'anta mine and correlate it with the regional tectonic framework in order to collaborate with the study of the tectonic evolution of the southern sector of the Serra do Espinhaço Setentrional Thrust and Fold Belt and its basement, southwards from the municipality of Caetité, Bahia, Brazil (Fig. 2). This study is of great importance and complements the data obtained by Machado (1977, 1983), Moraes et al. (1980) and Souza et al. (1984, 1990). Moreover, it presents an example of deformation in transpressional belts similar to what has been modeled by Wilcox et al. (1985), Sanderson and Machini (1994), Tikoff and Peterson (1998), and Jones et al. (2004), and also described for various regions of the world by Cunningham (2005, 2013), Sarkarinejad and Azizi (2008), Santimano and Riller (2012), Sarkarinejad et al. (2013), among others.

\section{REGIONAL GEOLOGICAL CONTEXT}

The Serra do Espinhaço Setentrional Thrust and Fold Belt, with maximum age dated as Cryogenian, is located in the northern sector of the Araçuaí Orogen and is positioned in the maximum inversion zone of the Paramirim Aulacogen (sensu Pedrosa-Soares et al. 2001), an extensional structure that evolved from approximately 1.7 to $0.67 \mathrm{Ga}$ (PedrosaSoares \& Alkmim 2011). This belt comprises units of the Gavião Block (sensu Barbosa \& Sabaté 2002), which comprise the basement of the Paramirim Aulacogen and the Lagoa Real Intrusive Suite, representatives of the plutonic rocks of the Statherian rift phase from the initial evolution of this aulacogen, as well as the units of metavolcanossedimentary rocks from the Espinhaço Supergroup and the Santo Onofre-Macaúbas Group (Figs. 2 and 4), which correspond to the cover units of the aulacogen. The Gavião Block is composed by the Gavião (Dalton de Souza et al. 2003) and Santa Isabel (Barbosa \& Moutinho da Costa 1973) complexes, as well as metavolcanossedimentary sequences. In the Gaviáo Complex, there are outcrops of tonalite-trondhjemite-granodiorite (TTG) orthogneisses, and Paleo-, Meso- and Neoarchean migmatites and granitoids (Cordani et al. 1985, 1992; Santos-Pinto 1996, Santos-Pinto et al. 1998; BastosLeal 1998, Peucat et al. 2002, Barbosa et al. 2012). In turn, the Santa Isabel Complex (Fig. 4) consists of tonalitic, granodioritic and granitic orthogneisses, with amphibolite and metapyroxenite enclaves, as well as eclogites, kinzigitic gneisses, calc-silicate rocks, itabirites, serpentine marbles, schistified meta-ultrabasic rocks and granulitic migmatites (Barbosa \& Moutinho da Costa 1973; Portela et al. 1976, Arcanjo et al. 2000). The geochronological database produced by Medeiros (2012) and Barbosa et al. (2013) suggests that these are in fact Mesoarchean rocks that were metamorphosed during the Rhyacian.

One of the most remarkable metavolcanossedimentary sequences of the Gavião Block is the Caetité-Licínio de Almeida sequence (Cunha et al. 2012), which hosts the iron and manganese deposits of the belt. This sequence is probably from the Paleoproterozoic Era (Cruz et al. 2014) and comprises itabirites, marbles (calcite-, dolomite- and manganese-rich), calc-silicate and carbonate-silicate rocks, metabasalts, metapelites with garnet (aluminous schists), quartzites and grunerite-cummingtonite schists (Machado 


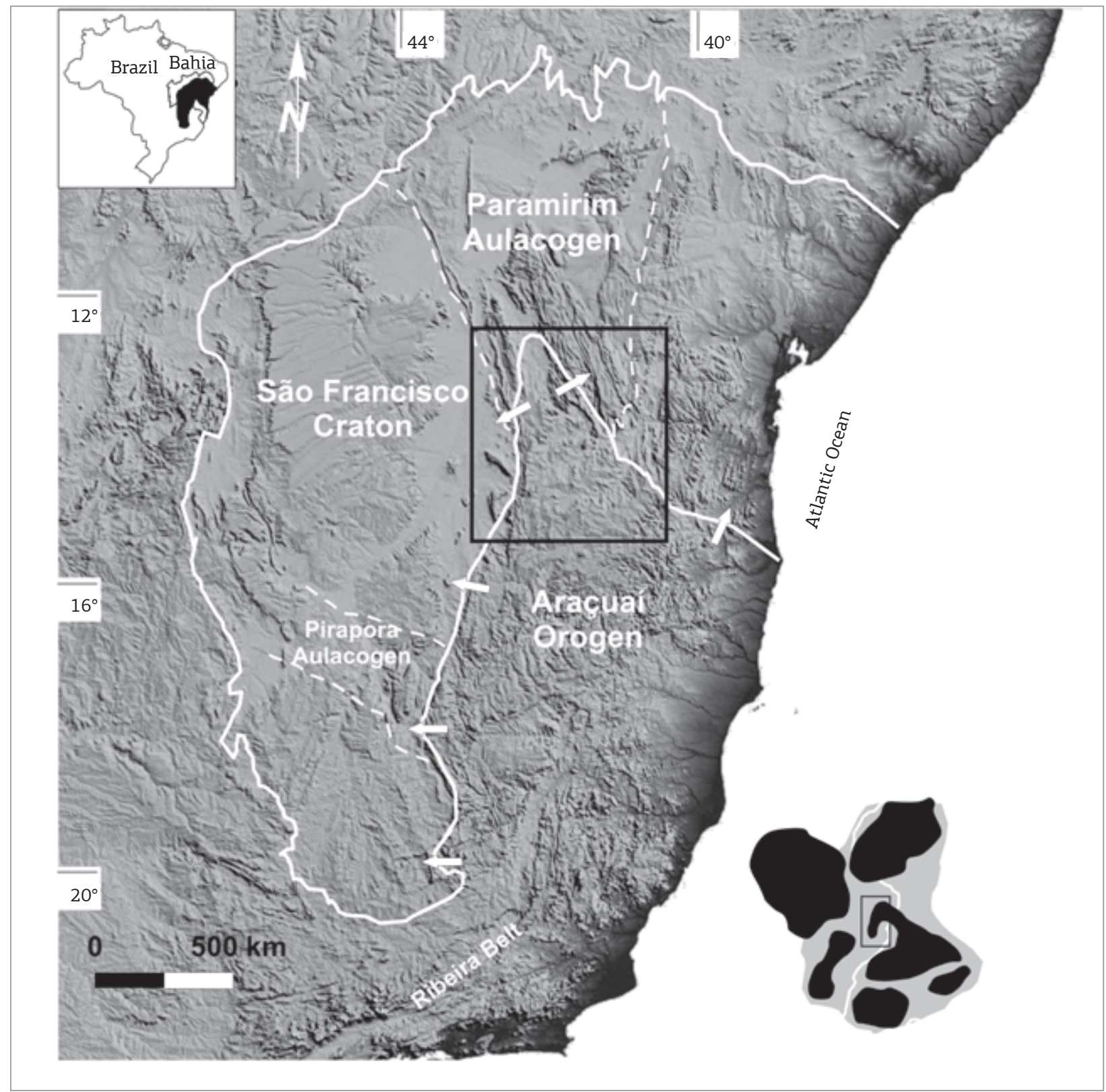

Figure 1. The Araçuaí Orogen in the Gondwana scenario, rebuilt through the juxtaposition of digital terrain models from the eastern sector of Brazil. The white arrows represent the vergence of the deformations of the Araçuaí Orogen. Modified from Alkmim et al. (2007). The box shows the location of Fig. 2.

1977, 1983; Moraes et al. 1980; Rocha et al. 1998; Borges 2008, 2012; Cruz et al. 2009; Cunha et al. 2012).

The Archean rocks and the metavolcanossedimentary sequences of the Gavião Block are intruded by Rhyacian, Orosirian and Statherian granitoids (Turpin et al. 1988; Cordani et al. 1992; Arcanjo et al. 2000; Bastos-Leal 1998; Bastos-Leal et al. 2000; Menezes-Leal et al. 2005). In the case of these granitoids, deformation is preferentially embedded in shear zones originating orthogneisses or foliated granitoids. Regarding the Rhyacian-Orosirian granitoids, calc-alkaline and alkaline rocks predominate (Menezes-Leal et al. 2005) with U-Pb ages that range between $2,324 \pm 6$ and $1,871 \pm$ 180 (Martins 2014). In turn, the Lagoa Real Intrusive Suite encompasses syenites, alkali feldspar granites and syenogranites. These alkaline rocks are from the continental intraplate environment (Teixeira 2000; Machado 2008) and mark the initial installation phase of the Paramirim Aulacogen (sensu Pedrosa-Soares et al. 2001). U-Pb (zircon and titanite) ages of approximately 1.7 Ga were obtained for these rocks by Turpin et al.(1988), Cordani et al. (1992), Pimentel et al. (1994) and Cruz et al. (2007a) and were interpreted as being a result of the crystallization of this suite. 

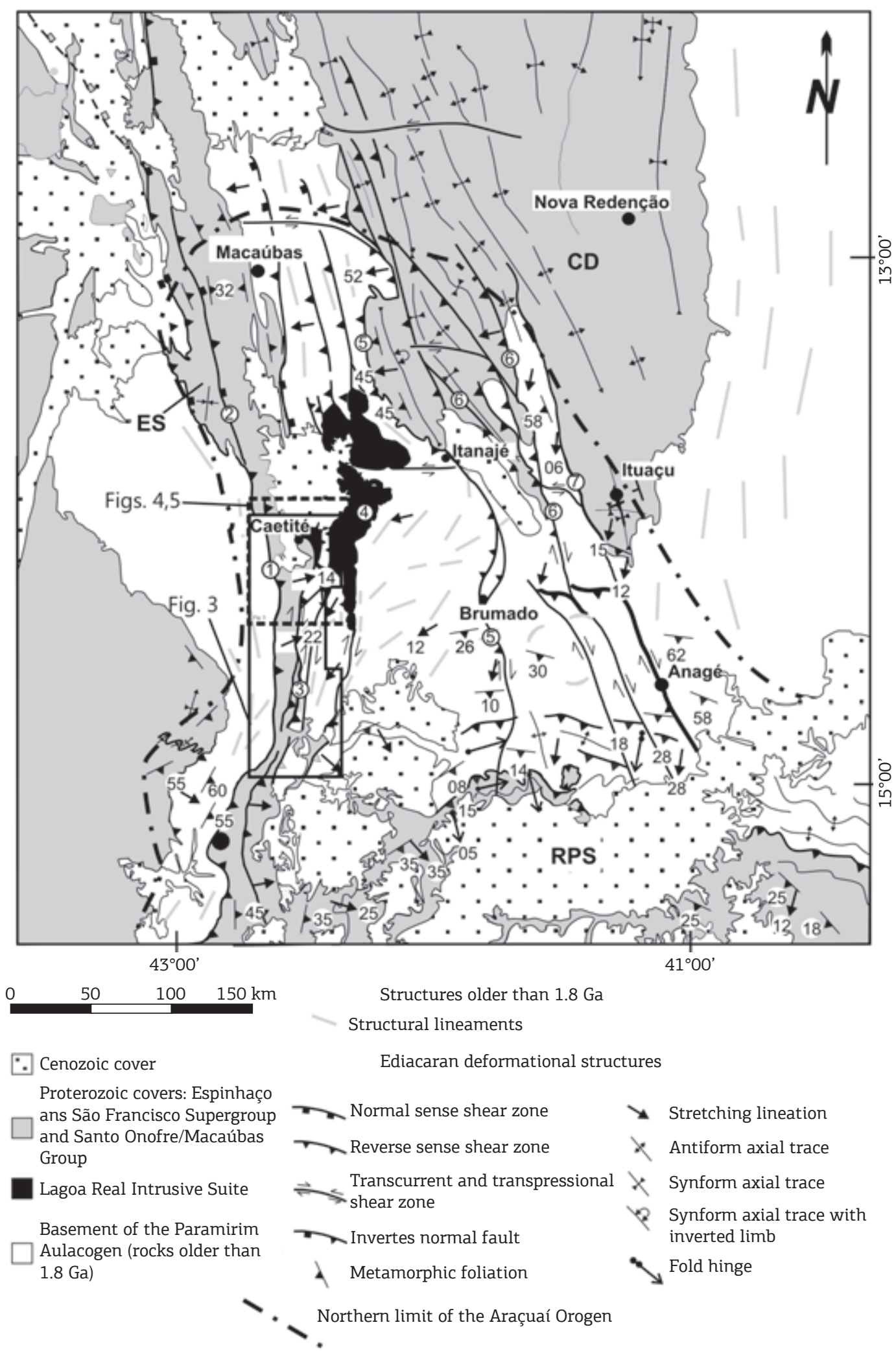

ES: Serra do Espinhaço Setentrional Fold Thrust Belt; CD: Chapada Diamantina Fold Thrust Belt; RPS: Rio Pardo Salient; Ediacaran Shear Zones 1: Santo Onofre; 2: Muquém; 3: Carrapato; 4: São Timóteo; 5: Paramirim-Brumado; 6: Cristalândia; 7: João-Correia-Barra do Mendes.

Figure 2. Map of the northern sector of the Araçuaí Orogen with the main structural traces. Modified from Cruz (2004). The boxes show the location of Figs. 3 to 5. 


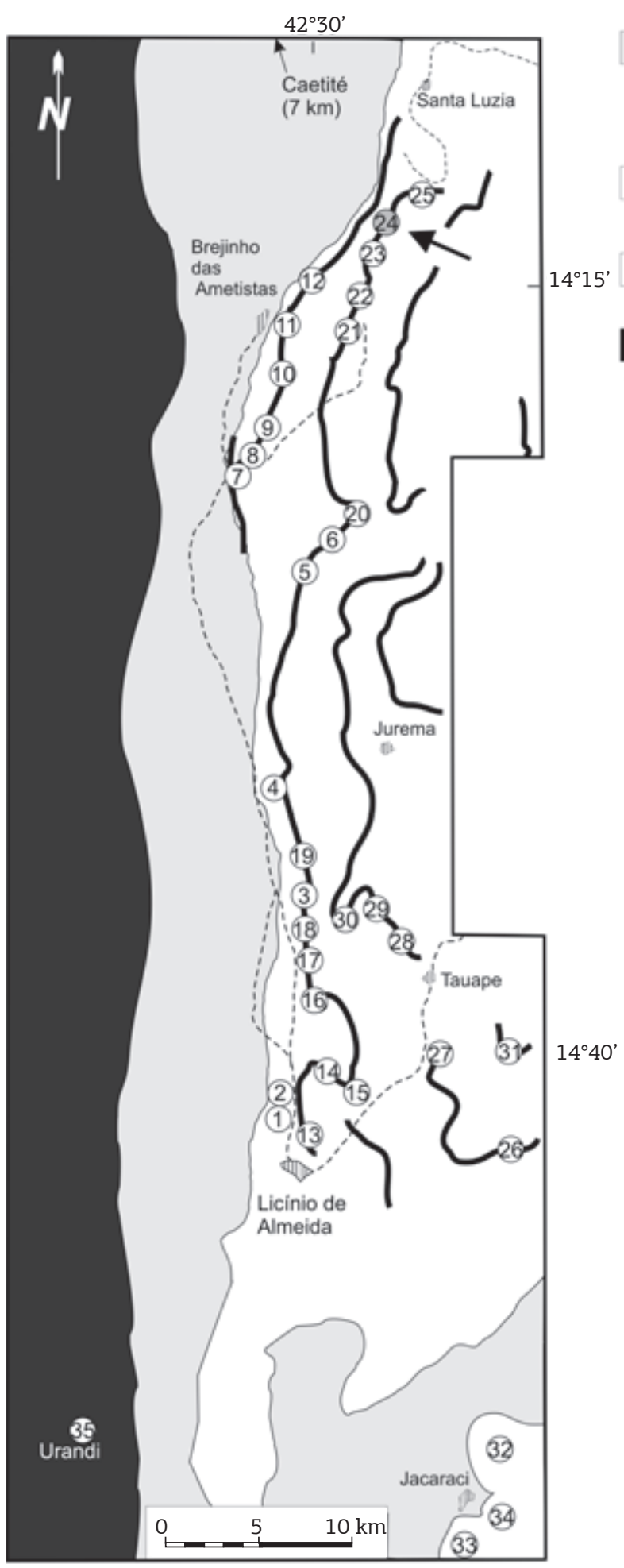

Proterozoic Covers

Undivided Espinhaço Supergroup and

Sano Onofre-Macaúbas Group

Caeté-Licínio de Almeida

Metavolcanossedimentary Sequence

Calcite marbles, calc-silicate rocks,

carbonate-silicate rocks, metabasalts,

grunerite-cummingtonite schists, metapelites,

with garnets (aluminous schists) and quartzites

- Itabirites and manganodolomite marbles

Santa Isabel Complex

Orthogneisses and granitoids

"n... Roads

Urandi-Caetité-Licínio de Alemeida

Irons-Manganese District

Mines

Caetité-Licínio de Almeida Subdistrict

(1) Mata

(2) Matinha

(3) Riacho Fundo

(4) Caiana

(5) Patinho

(6) Faca

(7) Pedra de Ferro

(8) Anta Velha

(9) Ventador

(10) Varginha

(11) Vai Quem Pode/Rapa

(12) Guaribos

13 Covão

(14) Louro

(15) Barreiro III

(16) Piedade

(17) Varas

(18) Figueiredo

(19) Pau do Rego

20 Açoita Cavalo (Marcos)

(21) Cobras

(22) Canabrava

23 Laranjeiras

24 Lagoa D’anta

(25) Morro das Cobras

26 Palmeiras

27) Canária

28 Lagoa da Vereda

29 Lagoa de Fora 1

(30) Lagoa de Fora 2

(31) São Pedro

(32) Tauá

33 Passagem

(34) Colônia-Riacho Cumprido

Urandi Subdistrict

35 Barreiro do Campo

Figure 3. Location of the manganese mines in the Caetité-Licínio de Almeida Iron-Manganese District. The arrow indicates the Lagoa D’anta mine. Modified from Rocha et al. (1998). 


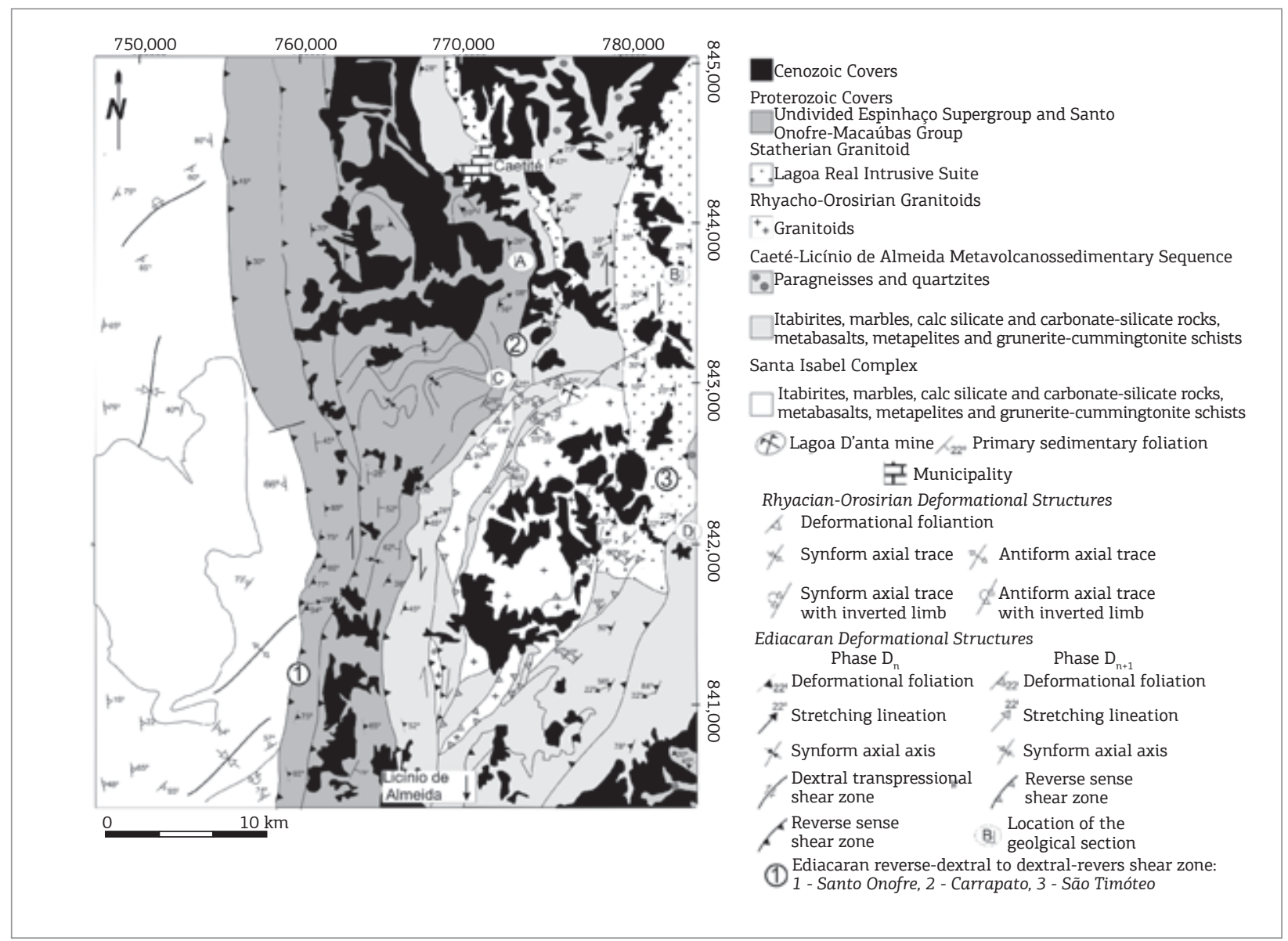

Figure 4. Geological map of the Serra do Espinhaço Setentrional Thrust and Fold Belt, southwards from the municipality of Caetité. The arrow indicates the location of the Lagoa D'anta mine. Modified from Cruz et al. (2009). The profiles of Fig. 5 are positioned in the map.

The Espinhaço Supergroup, of Statherian-Calymmian age, comprises a siliciclastic sequence with metavolcanic felsic rocks with crystallization ages (U-Pb, SHRIMP) of 1,731 \pm 5 and 1,582 $\pm 8 \mathrm{Ma}$ (Danderfer Filho et al. 2009). A crystal tuff sample from the Tombador Formation was dated by Guadagnin et al. (2015) at 1,436 $\pm 26 \mathrm{Ma}$. The Santo Onofre-Macaúbas Group, on the other hand, of Tonian age (Babinski et al. 2011), comprises feldspar meta-arenites and meta-quartz arenites, oligomictic metaconglomerates, phyllites, and hematite, graphite and/or manganese and sericite metapelites (Guimarães et al. 2012). These rocks are truncated by gabbroic and tholeiitic mafic dykes, distinguished through U-Pb (zircon) data in two groups of different ages Group I: 1,492 $\pm 16 \mathrm{Ma}$ (Loureiro et al. 2010); 1,514 Ma (Babinski et al. 1999) and 1,496 Ma (Guimarães et al. 2005); Group II: $854 \pm 23 \mathrm{Ma}$ (Danderfer Filho et al. 2009) and $834 \mathrm{Ma}$ (Loureiro et al. 2010).

In a regional scope, the studies performed by Cruz and Alkmim (2006) and Cruz et al. (2012) suggest the existence of three deformational structure groups in the northern sector of the Araçuaí Orogen:
1. structures older than the Paramirim Aulacogen, which are exclusive to the basement of the aulacogen. In other words, these structures reflect the Archean and/or Paleoproterozoic evolution of the Gavião Block. In the Santa Isabel Complex, located westwards from the Serra do Espinhaço Setentrional Thrust and Fold Belt (Fig. 4), Medeiros (2012) identified sinistral folds and shear zones, with general NNE-SSW to NE-SW orientation, which reflect a tension field oriented NW-SE. Westwards from this belt, gneissic banding, open to closed folds and dome structures predominate (Cruz 2004; Cruz et al. 2009);

2. extensional structures related to the evolution of the Paramirim Aulacogen, since the Statherian until the Stenian, which are preserved to the north of parallel $12^{\circ}$ $45^{\prime} \mathrm{S}$ and to the south of parallel $12^{\circ} 15^{\prime} \mathrm{S}$. This structure family comprises normal and dextral-normal shear zones (Danderfer Filho 2000) that evolved between 1.7 and 0.67 Ga (Pedrosa-Soares \& Alkmim 2011); and

3. structures related to the inversion of the Paramirim Aulacogen, which are partly the subject of the present study and which reworked the previous structures (Figs. 2, 4 and 5). 


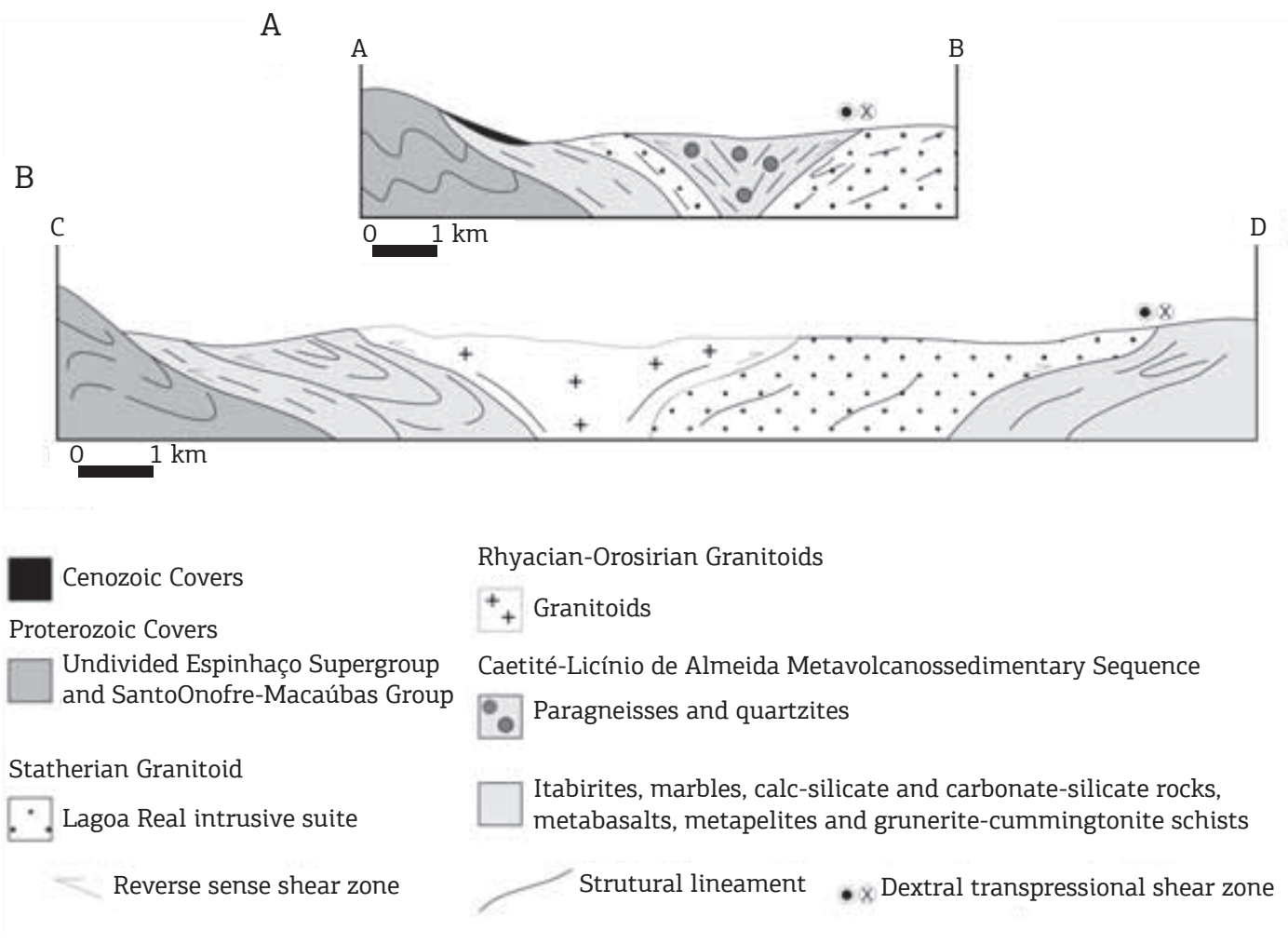

Figure 5. Schematic geological-structural sections transversal to the Serra do Espinhaço Setentrional Thrust and Fold Belt. The locations of the sections, as well as the legend of the units, are shown in Fig. 4.

They comprise shear zones that are generally oriented NNWSSE, as well as reverse, reverse-dextral or dextral movements and folds. According to Cruz and Alkmim (2006) and Cruz et al. (2012, 2014), these shear zones truncate or reuse the deformations older than 1.8 Ga present in the basement units of the aulacogen, as well as the rocks from the Lagoa Real Intrusive Suit, from the Espinhaço and São Francisco Supergroups and the Santo Onofre-Macaúbas Group. Ar-Ar ages between 483 and 586 Ma were obtained from phyllosilicates of the rocks hosted in the São Timóteo and Brumado-Paramirim shear zones (Fig. 2) by Bastos-Leal (1998), Cordani et al. (1992) and Guimarães et al. (2005). Moreover, in the Chapada Diamantina Thrust and Fold Belt, displays of the João Correia-Barra do Mendes shear zones truncate rocks of the Salitre Formation (Cruz \& Alkmim 2006). This formation can be correlated to the Sete Lagoas Formation, in the São Francisco Basin, which was dated by Babinski et al. (2007) through $\mathrm{Pb}-\mathrm{Pb}$ isochronic dating as $740 \pm 22 \mathrm{Ma}$. Thus, it was possible to establish the maximum age for the shear zones associated with the inversion of the Paramirim Aulacogen. Southwards, in the Araçuaí Orogen, these shear zones truncate the Tonian units of the Macaúbas Group (Babinski et al. 2011).
The folds related to the inversion of the Paramirim Aulacogen have various geometries, but in general they are open, normal-horizontal (sensu Fleuty 1964) and are observed in micro, meso and macro scales (Danderfer Filho 1990, 2000; Cruz \& Alkmim 2006; Bittencourt 2014). These folds are observed in units of the Espinhaço and São Francisco Supergroups, as well as in the Santo-Onofre-Macaúbas Group, in cover units of the Paramirim Aulacogen, and in the metavolcanossedimentary sequences of its basement. In the Caetité area, and associated with the units of the Santo Onofre-Macaúbas Group, Bittencourt (2014) mapped a mega refolded fold feature (sensu Ramsay \& Hubber 1987) involving graphite and aluminous schists with biotite, garnet, staurolite and quartz (Fig. 4). According to Cruz and Alkmim (2006), Cruz et al. (2012) and Bittencourt (2014), these structures reflect a WSW-ENE oriented shortening field.

\section{GEOLOGY OF THE LAGOA D'ANTA MINE}

\section{Lithological units}

The geological mapping of the Lagoa D'anta mine (Fig. 6) was performed in this study at a scale of 1:1,000 and the main 


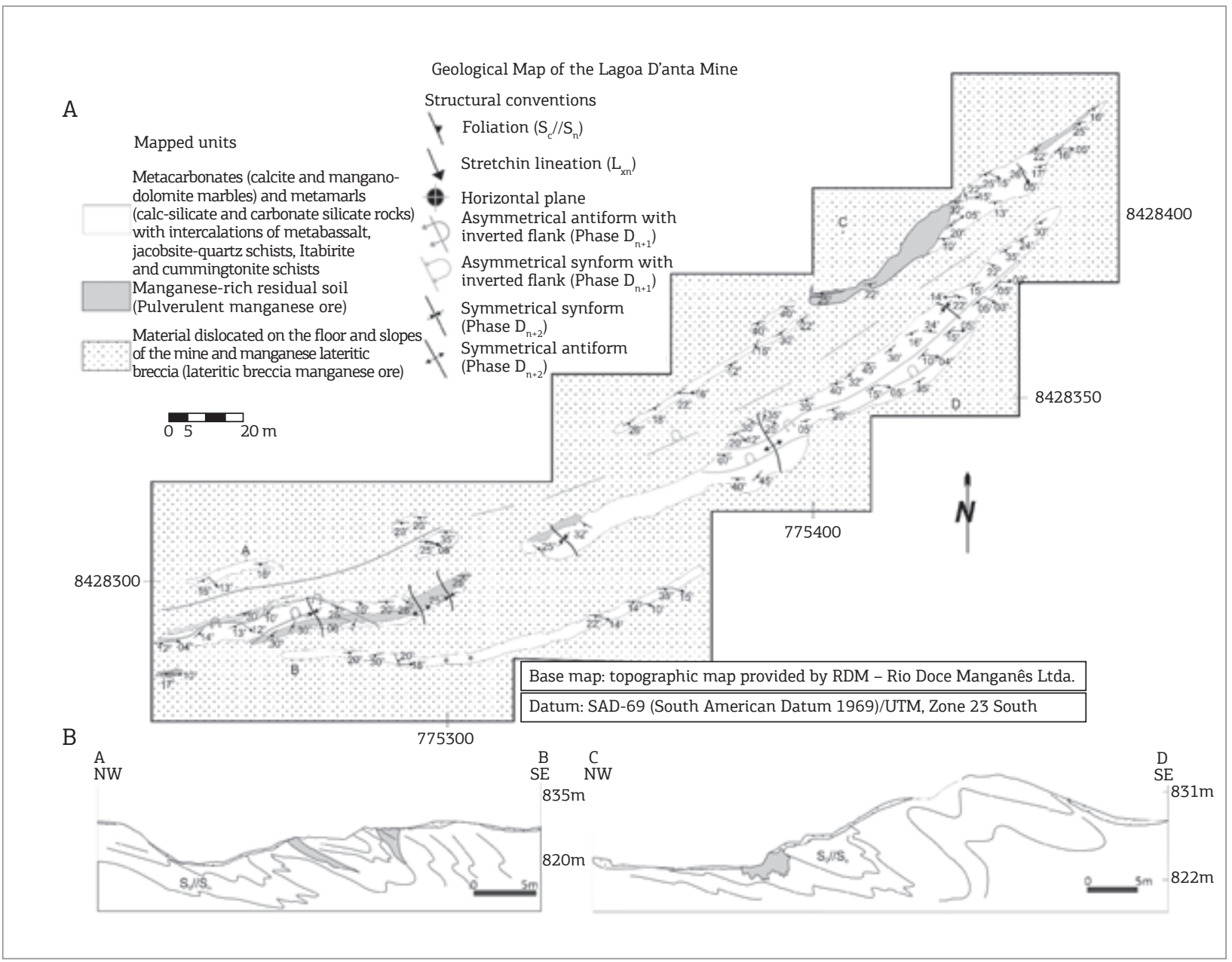

Figure 6. (A) Geological map of the Lagoa D'anta mine. (B) Geological sections showing the vergence to NW of the $F_{n+1}$ folds and the position of the manganese ore bodies.

focus was to delimitate the manganese ore bodies and gather information on the structural framework. This study allowed the mapping of the rocks adjacent to the magnesium mineralization (itabirite, cummingtonite-schist, metabasalt, calcite marble, calc-silicate and carbonate-silicate rocks) and the host rocks for the mineralization, which comprise the mine's manganese protore (manganese-dolomite marble with or without spessartite, jacobsite-quartz schist, as well as carbonate-silicate and calc-silicate rocks with manganese-dolomite and spessartite) (Borges 2012). Moreover, the soil is rich in manganese and is associated with the following types of ores (Fig. 7):

1. pulverulent, which is lenticular, with irregular geometry and erratic distribution; and

2. lateritic breccia. These ores are the product of supergene alteration of the aforementioned manganese protore in the mine.

Cummingtonite-schist and itabirite (Fig. 8A) occurred forming various levels and presented thickness of 1 and $15 \mathrm{~m}$, respectively. These rocks have variable proportions of magnetite, quartz and cummingtonite. Magnetite is partially replaced by martite in the itabirite. The metabasalt levels (Fig. 8B) are boudinaged and intercalate with levels of cummingtonite-schist and jacobsite-quartz schist (Fig. 7). These rocks are predominantly comprised of magnesiohornblende, titanite and andesine. Tremolite occurs on the edges of magnesiohornblende. Marbles (Fig. 8C), calc-silicate and carbonate-silicate rocks consist of calcite and manganese-dolomite carbonates. Minerals such as spessartite and manganese-cummingtonite are observed among rocks with manganese-dolomite, while hornblende and tremolite-actinolite occur associated with rocks with calcite.

A polygonal granoblastic structure predominates at the itabirite and marble levels (Figs. 9A and 9B). However, amphibolite-preferred orientation (nematoblastic microstructure) can occur in a very subordinate way, marking the metamorphic foliation of the rock. In cummingtonite-schists and metabasalt, the nematoblastic structure predominates (Figs. 9C and 9D), though polygonal grains of plagioclase with triple junctions can be observed in the metabasalt. 

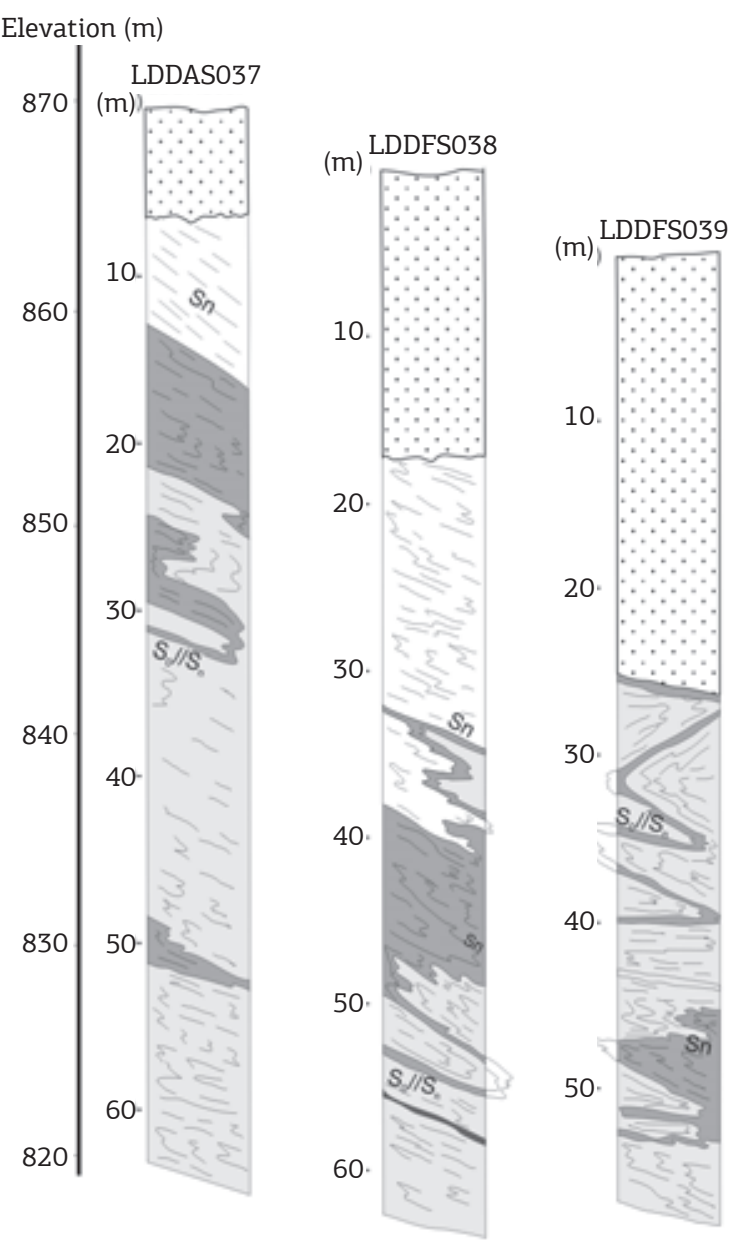

Iron-manganese lateritic breccia (lateritic breccia

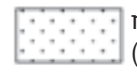
manganese ore), manganese-rich residual soil (pulverulent manganese ore) and remains of strongly weathered manganese metacarbonates

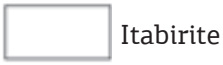

tabirite

Figure 7. Lithological profiles of the Lagoa D'anta mine in drill holes located in the surrounding area. Note the presence of parasitic folds of phase $D_{n+1}$.

Hydrothermal minerals, both in the country rocks and in the protore, are present in the veins of quartz, calcite (Fig. 10A), epidote grunerite (Fig. 10B) and magnetite (Fig. 10C) that truncate ductile structures.

\section{Manganese mineralization}

The manganese ore is represented by a residual soil that presents up to $66.80 \%$ of $\mathrm{MnO}_{2}$, comprising the high content ore of the mine (Fig. 8D), and is characterized as a pulverulent type of ore. The thickness of this mineralized zone is variable, ranging from 5 to $12 \mathrm{~m}$. A lateritic breccia ore also occurs, with up to $42 \%$ of $\mathrm{MnO}_{2}$ and thickness reaching $15 \mathrm{~m}$, which is possibly related to alluvial fans that were altered by supergene processes. According to Borges (2012), jacobsite-quartz schist, manganese-dolomite marbles with or without spessartite, as well as carbonate-silicate and calc-silicate rocks with manganese-dolomite and spessartite were altered by supergene processes that led to the observed concentration of $\mathrm{MnO}$ (Fig.
8D) and to the creation of a pulverulent ore. This ore is rich in cryptomelane (Figs. 9E and 9F) and is frequently associated with a siliceous microcrystalline material (Fig. 8E), which is a result of the supergene alteration from garnet to manganese oxide, denominated siliceous (Borges 2012) alteroplasma (sensu Delvigne 1998). Superficial processes seem to have contributed towards the creation of manganese lateritic breccia by means of the installation of alluvial fans, manganese lixiviation and supergenesis. Mineralization age has not been determined yet.

\section{Structural framework}

According to Cruz et al. (2009), the Lagoa D'anta mine is positioned between two shear zones (Figs. 2 and 4) called Carrapato (Danderfer Filho 2000), or Eastern Border (Rocha et al. 1998), and São Timóteo (Cruz 2004; Cruz \& Alkmim 2006; Cruz et al. 2012). In this sector of the Serra do Espinhaço Setentrional Thrust and Fold Belt, these shear zones present a general N-S orientation, NE and SW dips, respectively with 

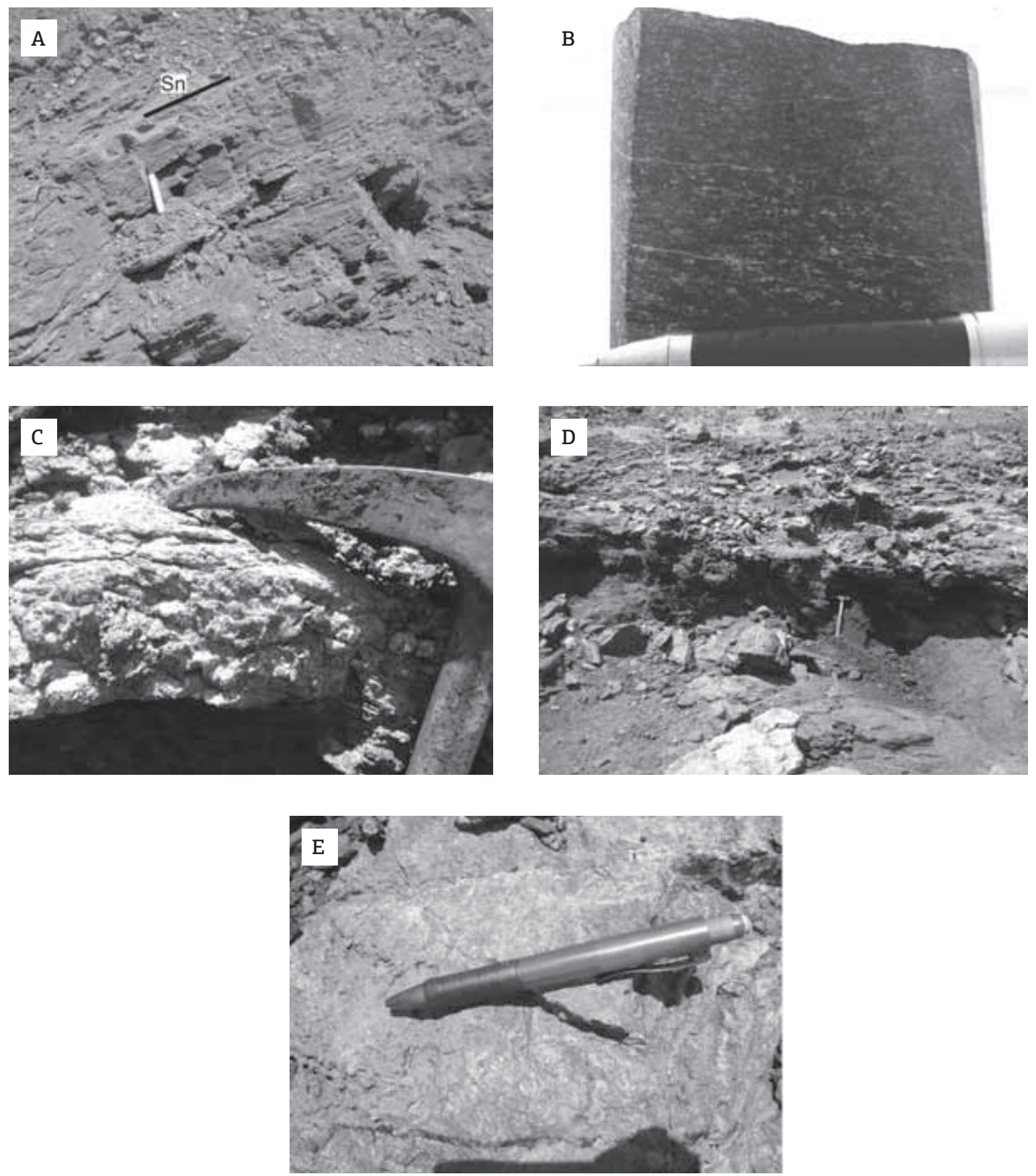

Figure 8. Mapped lithologies in the Lagoa D'anta mine. (A) Itabirite. (B) Metabasalt. (C) Magnetite-spessartitemarble. (D) Pulverulent manganese ore. (E) Siliceous alteroplasma.

values ranging between $20^{\circ}$ and $45^{\circ}$. From north to south, the movement varies from reverse-dextral to dextral-reverse (Cruz \& Alkmim 2006; Cruz et al. 2009, 2014; Bittencourt 2014). The main movement indicators observed on the XZ plane are $\mathrm{S} / \mathrm{C} / \mathrm{C}$ ' structures. When shear zones develop in granitoids, delta and sigma structures are created. In these shear zones, the stretching lineation ranges, in general, from medium to low obliquity and is preferentially oriented $053^{\circ} / 43^{\circ}$. The geological sections presented in Fig. 5A suggest the existence of a transpressional pop-up structure generally $\mathrm{N}$-S oriented encompassing the units of the Caetité-Licínio de Almeida Metavolcanossedimentary Sequence, the Lagoa Real Intrusive Suite, as well as the units of the Espinhaço Supergroup and Santo Onofre-Macaúbas Group in the Serra do Espinhaço Setentrional Thrust and Fold Belt. 

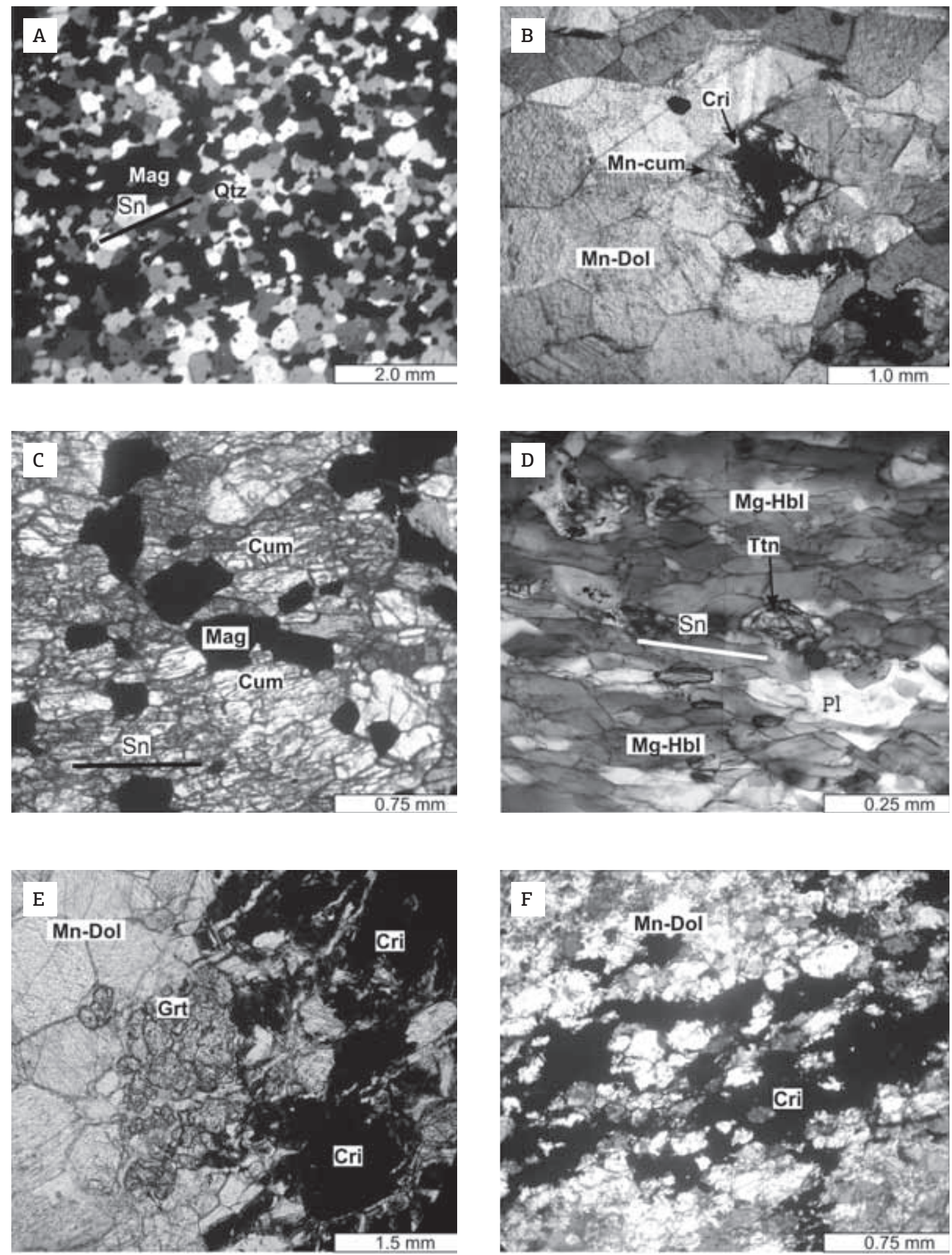

Mag: magnetite; Qtz: quartz; Mn-dol: manganodolomite; Mn-Cum: manganocummingtonite; Cri: cryptomelane; Cum: cummingtonite; Mg-Hbl: magnesiohornblende; Ttn: titanite; Grt: garnet (spessartite); Pl: plagioclase.

Figure 9. Photomicrographs showing the microstructures and minerals observed in rocks from the Lagoa D'anta mine. (A and B) Polygonal granoblastic microstructure in itabirite and manganese-dolomite marble, respectively. (C and D) Nematoblastic microstructure in cummingtonite-schist and metabasalt, respectively. (E and F) Cryptomelane generated through the alteration of manganese-dolomite marbles with spessartite. 


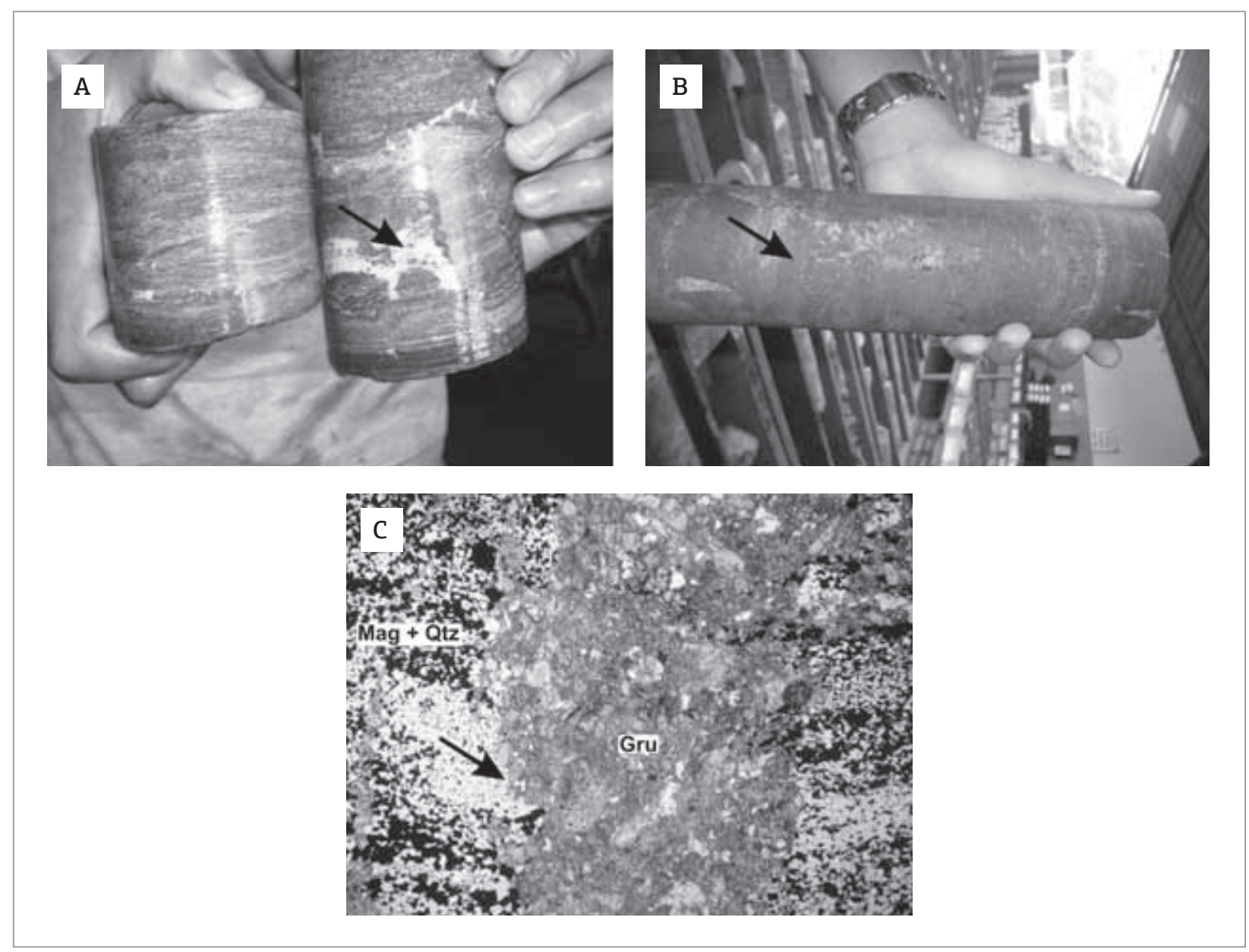

Figure 10. Macroscopic aspects of the calcite (A, arrow) and magnetite (B, arrow) veins truncating $S_{n}$ foliation in metabasalt. In $(C)$, we can observe the photomicrograph of a grunerite vein (Gru, arrow) truncating levels with variable proportions of magnetite (Mag) and quartz (Qtz) in itabirite.

Between the Carrapato and São Timóteo shear zones (Fig. 4), there are reverse subsidiary shear zones, with general NE-SW orientation, which truncate the N-S structures. These subsidiary zones also present double vergence and are possibly associated with another pop-up structure, though they are obliquely positioned in relation to regional structures. In this region, the dip of the shear zones ranges between $30^{\circ}$ and $60^{\circ}$, while the stretching lineation presents high obliquity. In the NW branch, in the surroundings of the Lagoa D'anta mine, a slightly tilted (sensu Fleuty 1964), closed and horizontal synform fold was mapped by Cruz et al. (2009). This fold is positioned between two shear zones that comprise the NW branch of the pop-up structure with NE-SW orientation, as shown in Fig. 5B.

\section{Characterization of the deformational structures of the Lagoa D'anta mine}

The structural survey led to the identification of a set of ductile and brittle structures. The oldest deformational structure was a compositional banding $\left(\mathrm{S}_{0} / / \mathrm{S}_{\mathrm{n}-1}\right)$ observed in rootless intrafolial isoclinal folds and transposed by $S_{n}$ foliation (Fig. 11A). The banding $\left(\mathrm{S}_{0} / / \mathrm{S}_{\mathrm{n}-1}\right)$ is characterized by the alternation of manganese-dolomite marbles, calc-silicate rocks, metabasalt and itabirite. Garnet and grunerite, as well as carbonates and polygonal granoblastic microstructure plagioclase, are observed associated with this $\mathrm{S}_{0} / /$ $\mathrm{S}_{\mathrm{n}-1}$ surface. Schistosity is observed parallel to this banding $\left(S_{n-1}\right)$, present in rocks with amphibolites.

The dominant structure of the mine is $S_{n}$ schistosity (Figs. 6, $8 \mathrm{~A}$ and $11 \mathrm{~B})$. This feature is also parallel to a compositional banding $\left(\mathrm{S}_{0} / / \mathrm{S}_{\mathrm{n}}\right)$ that alternates the rocks from the Lagoa D'anta mine (Figs. 6, 7, 11B and 11D). In general, $S_{n}$ is oriented NE-SW and the dip of these structures range between $0^{\circ}$ and $40^{\circ}$, with maximum plane at $155^{\circ} / 18^{\circ}$ (Fig. 12A). $S_{n}$ schistosity is characterized by the preferred orientation of: 1. grains of cummingtonite and quartz in itabirite;

2. grains of cummingtonite in cummingtonite-schists (Fig. 9C); 

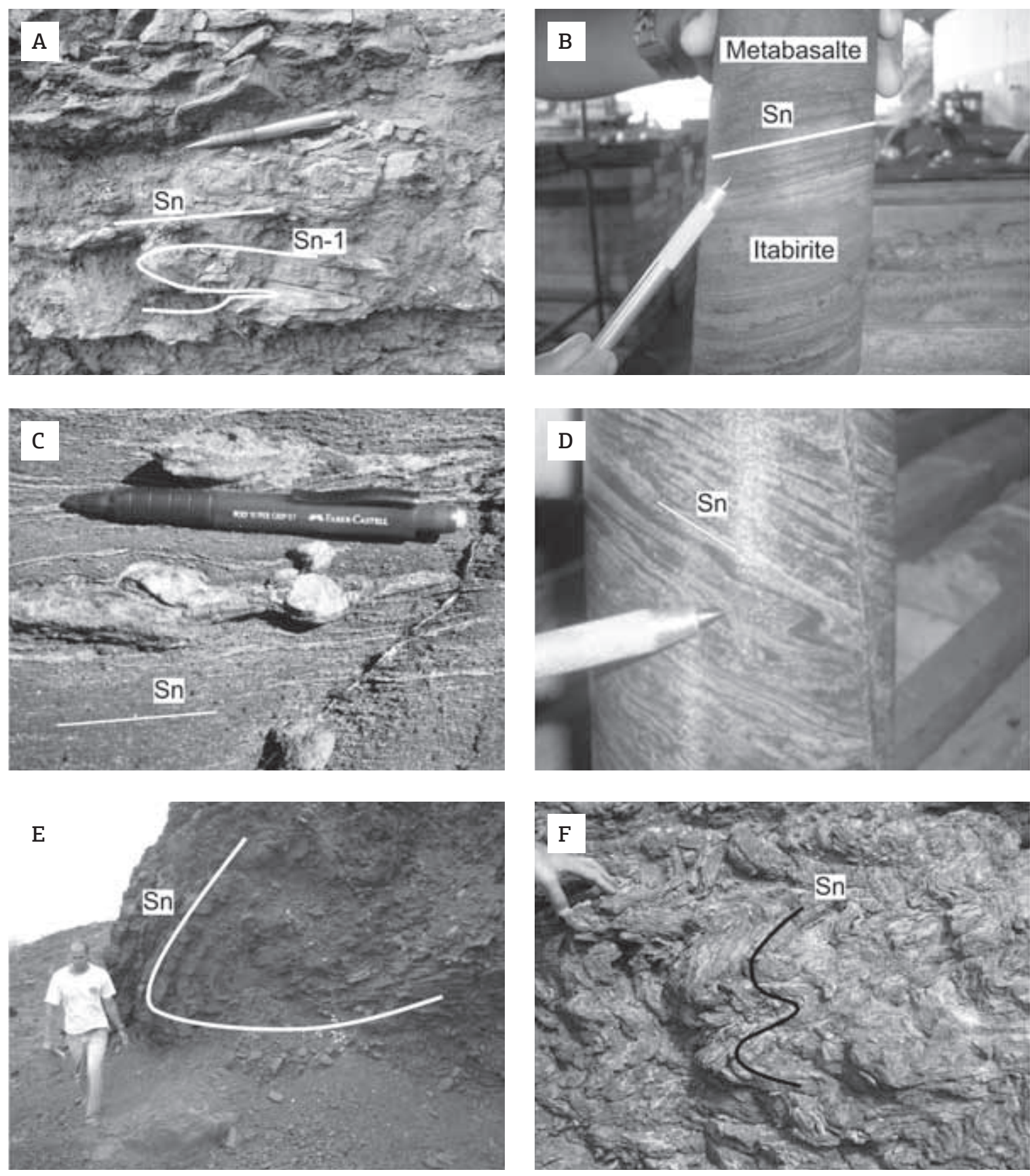

Figure 11. Deformational structures of the Lagoa D'anta mine. (A) Rootless isoclinal intrafolial fold involving $\mathrm{S}_{0} / / \mathrm{S}_{n-1}$ in a calc-silicate rock. (B) Compositional banding $\left(\mathrm{S}_{0} / / \mathrm{S}_{n}\right)$ by the alternation of levels that are rich in cummingtonite schist and metabasalt. (C) Symmetrical boudin of a quartz vein in spessartite-tremolite manganese-dolomite marble. (D and E) Parasitic asymmetrical folds in a drill hole and in an outcrop, respectively, in itabirite. (F) Parasitic symmetrical fold in a calc-silicate rock.

3. grains of cummingtonite and tremolite-actinolite in marbles, calc-silicate and carbonate-silicate rocks; and

4. grains of tremolite and magnesiohornblende in metabasalt (Fig. 9D).
Stretching lineation $\left(\mathrm{L}_{\mathrm{xn}}\right)$ was identified and showed amphibolite and quartz-preferred orientation. This lineation is preferably oriented $093^{\circ} / 15^{\circ}$ (Fig. 12B). In this context, amphibolite grains and quartz layers are boudinaged. 


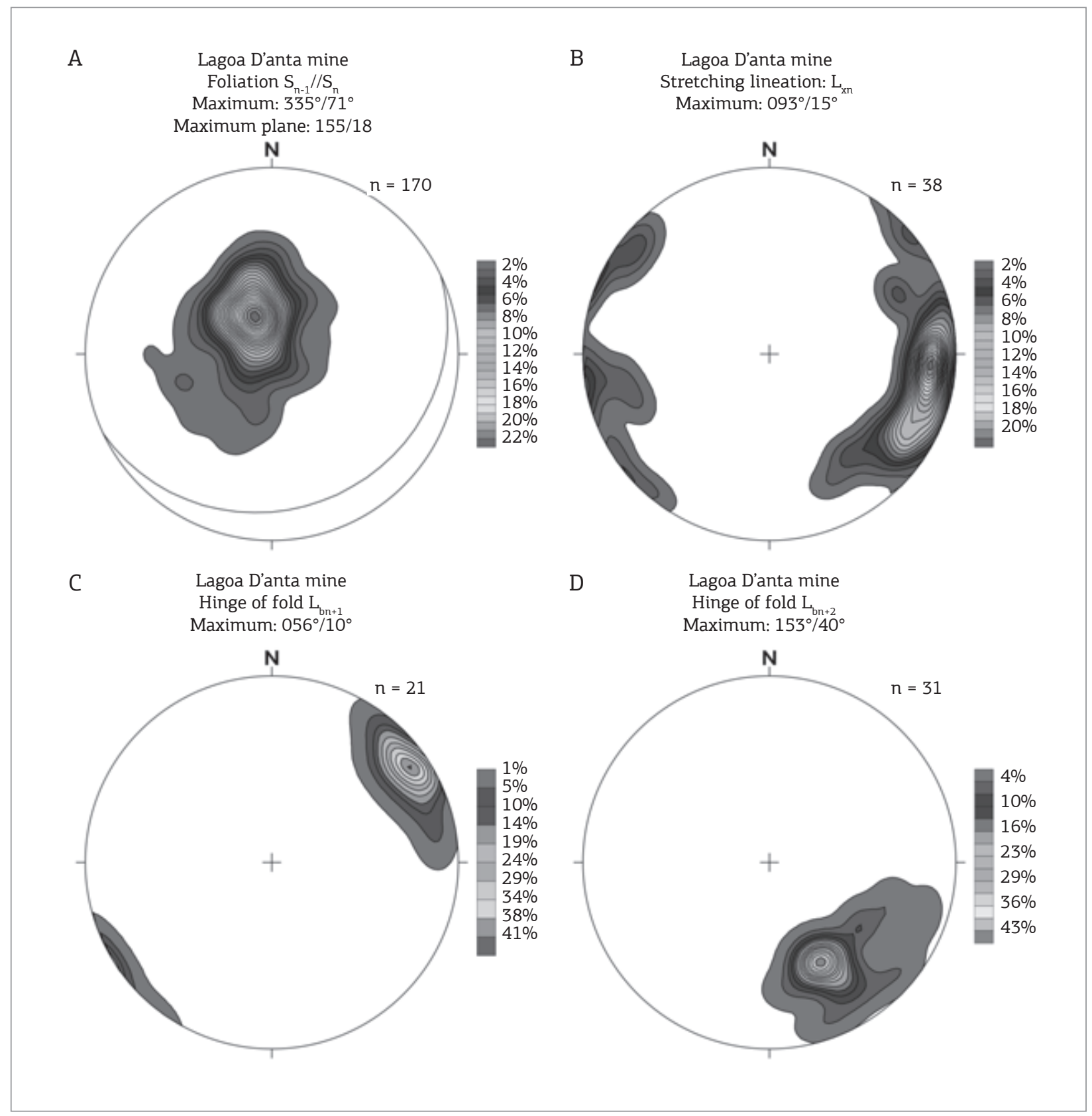

Figure 12. Stereographical representation of the mapped structures of the Lagoa D'anta mine. (A) Polar isodensity diagram for the foliation planes $\left(\mathrm{S}_{n}\right)$. (B) Isodensity diagram for the stretching lineation $\left(\mathrm{L}_{x n}\right)$. (C) Isodensity diagram for the hinge line $\left(\mathrm{L}_{\mathrm{bn+1}}\right)$. (D) Isodensity diagram for the hinge line $\left(\mathrm{L}_{\mathrm{bn}+2}\right)$. Lower hemisphere, diagram with the same area. Values calculated for $1 \%$ of the circle's area.

This structure is oriented subparallel to the intersection lineation between foliations $S_{n-1}$ and $S_{n}$.

Quartz levels and levels parallel to $S_{n}$ are boudinaged not only on the XY plane of the foliation, but also on the $\mathrm{XZ}$ plane (Fig. 11C). In general, boudins presented 5 to $10 \mathrm{~cm}$ in length, were symmetrical and associated with pinch-and-swell structures and to passive folding (sensu Fossen 2010), in this case, the folds were settled between the boudins.
The $S_{n}$ foliation is folded in three hierarchical scales. The main envelopment of folding phase $\mathrm{F}_{\mathrm{n}+1}$ is a weakly tilted horizontal mega-synform fold (sensu Fleuty 1964) (Fig. 6) with wavelength of approximately $3 \mathrm{~km}$. The axial plane dips towards SE and, thus, vergence is oriented towards NW. No axial plane foliation was found in this structure and one of the flanks of this fold is inverted. The parasitic folds range from being recumbent to weakly tilted horizontal and are non-cylindrical, disharmonic and present a closed curved 
hinge (sensu Fleuty 1964). These folds, which present higher hierarchy and have wavelengths of up to $10 \mathrm{~m}$ long, represent parasitic structures of the regional folds mapped in the NW branch of the pop-up structure with NE-SW orientation (Fig. 5B). These second-order folds were mapped in the scale of the mine and host third-order parasitic structures, which are asymmetrical in $\mathrm{S}$ and $\mathrm{Z}$ and symmetrical in $\mathrm{M}$ (Figs. 11D, 11E and 11F). The hinge lines of these structures are preferentially oriented at $056^{\circ} / 10^{\circ}$ (Fig. 12C).

A second set of folds $\left(\mathrm{F}_{\mathrm{n}+2}\right)$ can be found in the mine where the hinges are generally oriented NW-SE. In this case, the folds are smooth to open, disharmonic, with hinges at a general $153^{\circ} / 40^{\circ}$ orientation, and with a subvertical axial plane (Fig. 12D). These are classified as moderately tilted (sensu Fleuty 1964). Wavelengths ranged between 30 and $120 \mathrm{~m}$. These structures present general NW-SE orientation (Fig. 6); in other words, en èchelon regarding the Carrapato and São Timóteo shear zones, both of which are dextral transpressional shear zones.

Veins are distributed in a non-systematic display, mainly forming quartz, calcite (Fig. 10A), epidote, grunerite (Fig. 10B) and magnetite (Fig. 10C) stockwork structures that truncate the previously described ductile structures. The veins measured from 0.1 to $5 \mathrm{~cm}$ in width and up to $10 \mathrm{~cm}$ in length. The formation of these structures is related to late hydrothermal activity in the development of both generations of folds found in the mine.

In the mine, NE-SW and NW-SE fracture families truncate the folds. An intense association between supergene alteration zones and the presence of fractures is observed especially where the protore still predominates. In these sectors, narrow levels of cryptomelane are observed (Fig. 9E and 9F) associated with these brittle structures. In the domains with the greatest supergene alteration, this relationship is disguised by the presence of a pulverulent material that reaches $62.8 \%$ of $\mathrm{MnO}$ (Borges 2012).

\section{STRUCTURAL EVOLUTION AND REGIONAL CORRELATION}

The structural survey performed in the present study allowed the identification of four deformational compressional phases. The first one $\left(D_{n-1}\right)$ is associated with the presence of compositional banding $\left(\mathrm{S}_{0} / / \mathrm{S}_{\mathrm{n}-1}\right)$ and schistosity $\left(\mathrm{S}_{\mathrm{n}-1}\right)$, which were found in rootless intrafolial isoclinal folds. Considering the scale of the mine, this compositional banding is transposed by a $S_{n}$ schistosity that hosts mineral stretching lineation $\left(\mathrm{L}_{\mathrm{xn}}\right)$, both of which are from phase $D_{n}$. These structures were generated through the development of inter- and intra-strata shear zones, which in turn are associated with the Carrapato and São Timóteo shear zones. In the Lagoa Real Intrusive Suites and units of the Santo-Onofre Group, stretching lineation is oriented NE-SW to SSW-NNE (Fig. 4), while in the CaetitéLicínio de Almeida Metavolcanossedimentary Sequence, this lineation is generally oriented NE-SW to E-W. The distribution of planar and linear structures suggests the existence of a pop-up structure oriented N-S (Fig. 5A). As shortening increased and under transpressional conditions, another structure of phase $\mathrm{D}_{\mathrm{n}+1}$ was formed, comprising a pop-up structure oriented NE-SW (Fig. 5B). The formation of this structure culminated in the development of reverse shear zones, which caused the thrust of Rhyacian granitoids over the CaetitéLicínio de Almeida Metavolcanossedimentary Sequence in the west branch of the pop-up structure (Fig. 5B), as well as culminated in the formation of $F_{n+1}$ folds.

These structures from phases $D_{n}$ and $D_{n+1}$ of the basement of the Serra do Espinhaço Setentrional Thrust and Fold Belt correspond to the structures from phase $\mathrm{D}_{\mathrm{p}}$ described by Cruz and Alkmim (2006), which were interpreted by these authors as being related to the inversion of the Paramirim Aulacogen. According to the same authors, southwards from the municipality of Caetité, shear zones with reverse-dextral to dextral-reverse movements predominate and, further south, at the latitude of the Lagoa D'anta Mine, shear zones with dextral-reverse movement predominate. These structures are thought to be related to the involvement of the basement of the Paramirim Aulacogen in the deformation of the Espinhaço Supergroup, the São Francisco Supergroup and the Santo-Onofre-Macaúbas Group (cover units of the aulacogen), as well as the Lagoa Real Intrusive Suite during the Ediacaran. The involvement of the basement during the inversion of this sector of the Paramirim Aulacogen occurred through the activation of shear zones with reverse-dextral to dextral-reverse movement, called Carrapato and São Timóteo (Fig. 4), which truncate the contact between the basement and the aulacogen cover, as well as through the development of folds in the Caetité-Licínio de Almeida Metavolcanossedimentary Sequence. During this inversion, according to Cruz and Alkmim (2006), other transpressional shear zones were also activated, such as the Santo Onofre, Muquém, Paramirim-Brumado, Cristalândia and João Correia-Barra do Mendes shear zones (Fig. 2).

Together, these structures correspond to a main maximum tension field oriented WSW-ENE, which was interpreted by Cruz and Alkmim (2006) as being related to the collisions between the São Francisco-Congo, Amazonian and Rio de la Plata plates during the Ediacaran. The Ediacaran age was estimated for the deformations in the São Timóteo shear zone (Fig. 2) based on a lower interception that occurred approximately 500 Ma obtained by Turpin et al. (1988). These authors dated zircons from samples collected in orthogneisses that were generated by the deformation of the Lagoa Real Intrusive Suite 
during the inversion of the Paramirim Aulacogen. As previously mentioned, ages between 483 and 586 Ma were obtained in phyllosilicates of rocks from other shear zones of this same sector of the Araçuaí Orogen by Bastos-Leal (1998), Cordani et al. (1992) and Guimarães et al. (2005).

At the Lagoa D'anta mine, the deformational history associated with the evolution of the Carrapato and São Timóteo shear zones is more complex when compared to the other sectors of the Serra do Espinhaço Setentrional Thrust and Fold Belt and involves the nucleation of structures related to more than one deformational phase, namely $\mathrm{D}_{\mathrm{n}}$ and $\mathrm{D}_{\mathrm{n}+1}$. In other words, while to the north of the mines the structures related to these shear zones suggest the existence of only one phase, $D_{n}$, in the area of the mine, more than one deformational phase were observed. The structures of phase $\mathrm{D}_{\mathrm{n}+1}$ truncate those from phase $\mathrm{D}_{\mathrm{n}}$, which present regional distribution. In this case, a pop-up structure oriented NE-SW was formed, as well as centrifugal vergence towards NW and SE. This structure is oblique in relation to the Carrapato and Sáo Timóteo shear zones and was responsible for the thrusting of the units of the Caetité-Licínio de Almeida Metavolcanossedimentary Sequence (basement of the Paramirim Aulacogen) over the Tonian units of the Santo Onofre-Macaúbas Group (sedimentary cover of the Paramirim Aulacogen) and of the Rhyacian granitoids (Cruz et al. 2009) over the Statherian rocks of the Lagoa Real Intrusive Suite (Fig. 5) (Cruz \& Alkmim 2006; Cruz et al. 2007a, 2009, 2014; Bittencourt 2014).

In N-S dextral transpressional systems, structures oriented NE-SW should be extensional, not compressional as those observed in the area of the Lagoa D'anta Mine. The presence of a pop-up structure oriented NE-SW in the identified transpressional system suggests:

1. deformation controlled by the reactivation of old basement structures, such as the transference zones of the Paramirim Aulacogen or shear zones older than 1.8 Ga, with general NE-SW orientation. Basement inheritance is thought to control deformation given the strong similarity between the trend of structures older than $1.8 \mathrm{Ga}$ (obtained by Medeiros (2012) in the Santa Isabel Complex, westwards from the Espinhaço Setentrional Thrust and Fold Belt; Fig. 4) and the NE-SW orientation of the pop-up structure mapped in the present study;

2. deformation partitioning into sectors with oblique compressional shear zones oriented N-S and frontal compressional shear zones oriented NE-SW; and

3. the intensity of regional shortening. The increase in deformation from north to south at the northern sector of the Araçuaí Orogen has already been shown in studies conducted by Moutinho da Costa and Inda (1982), Danderfer Filho (1990, 2000), Cruz and Alkmim (2006) and Cruz et al. (2007b).
The progression of deformation and maintenance of the WSW-ENE tension field is believed to have led to the development of open folds in phase $\mathrm{D}_{n+2}$. These folds are considered to be non-coaxial in relation to the folds from phase $\mathrm{D}_{\mathrm{n}+1}$ and are distributed en èchelon in relation to the Sáo Timóteo and Carrapato shear zones, as well as controlled by regional tensions. The geometric arrangement obtained for phase $\mathrm{D}_{\mathrm{n}+2}$, in which there is the development of NE-SW oriented folds that are moderately tilted (sensu Fleuty 1964) and obliquely positioned in relation to the Carrapato and São Timóteo dextral-reverse transpressional shear zones (both with N-S orientation; Fig. 13), is similar to the model for Wrench Folds, produced in laboratory by Wilcox et al. (1985). However, in the area of the Espinhaço Setentrional Thrust and Fold Belt, located southwards from the municipality of Caetité (Fig. 2), the Carrapato and São Timóteo shear zones are not vertical, as expected in the model by Wilcox et al. (1985), but tilted, as expected in the models by Tikoff and Teyssier (1994), Jones et al. (2004) and Sarkarinejad et al. (2013). Moreover, the $\mathrm{F}_{\mathrm{n}+2}$ folds are moderately tilted (sensu Fleuty 1964) and not normal-horizontal as expected in the model by Wilcox et al. (1985). This probably occurs because the folds from this phase developed on a tilted surface, which was previously folded by phase $\mathrm{D}_{\mathrm{n}+1}$, unlike the model proposed by the author, which considers horizontal layers.

The structures identified in the sector of the Espinhaço Setentrional Thrust and Fold Belt located southwards from the municipality of Caetité reflect a transpressional system, as defined by Sanderson and Machini (1994). The driving force of these deformations would be the sequence of oblique collisions between the São Francisco-Congo, Amazonian and Rio de La Plata plates, during the Ediacaran (Fig. 13A). In turn, these collisions are thought to have caused the inversion of the Paramirim Aulacogen, which involved its basement (Cruz \& Alkmim 2006) and the formation of a new intracontinental orogenic zone. This intracontinental orogenic zone seems to be associated with a transpressional system dominated by simple shearing (Fig. 13B), as defined by Tikoff and Teyssier (1994). Modern examples of this type of orogen are found in Iran (Walker \& Jackson 2004) and Mongolia (Cunningham 2005, 2013, among others). At the scale of the Espinhaço Setentrional Thrust and Fold Belt, the mapped structures suggest deformation partitioning and are an example of dextral transpressional systems that involve basements in the deformation of the cover of aulacogens located in intracontinental domains in which there is a strong influence of basement inheritance.

The mineral association that predominates in the Lagoa D'anta mine, where the Licínio de Almeida Metavolcanossedimentary Sequence is located, consists of 


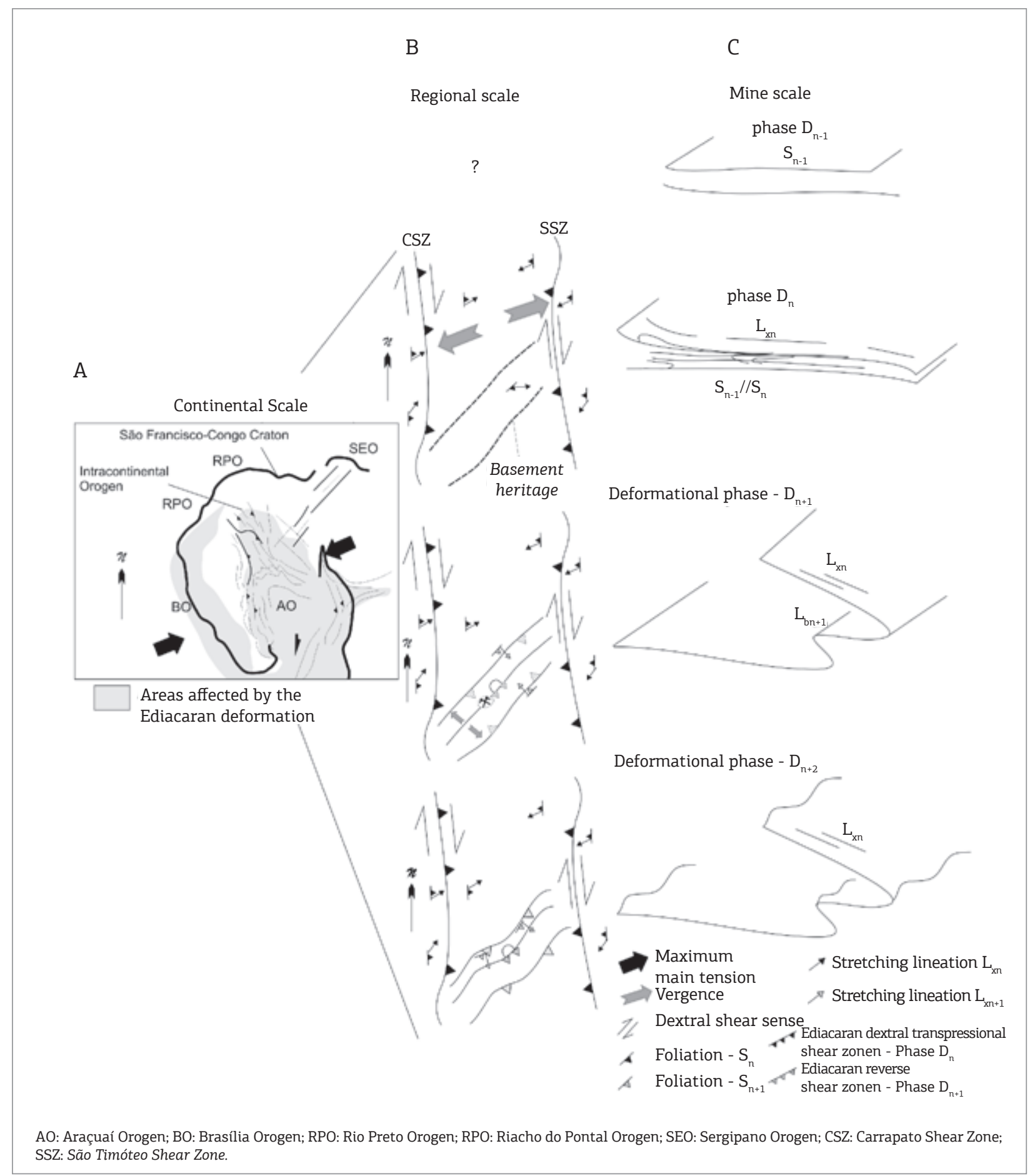

Figure 13. Deformational evolution model proposed for the Lagoa D'anta mine and regional correlation at continental (A), regional (B) and mine (C) scales. The legend of Fig. B is equal to the legend of Fig. 5.

cummingtonite, magnetite and quartz in itabirites, magnesiohornblende and andesine comprising a polygonal granoblastic structure in spessartite metabasalts, manganocummingtonite and mangano-dolomite in marbles (Borges 2012). On the other hand, in the surroundings of Caetité, Bittencourt (2014) obtained mineral paragenesis with garnet, biotite and staurolite (without chlorite) for aluminous schists of the Santo OnofreMacaúbas Group in the Carrapato shear zone. This finding suggests temperature conditions between 660 and $680^{\circ} \mathrm{C}$ for Ediacaran metamorphism in the Serra do Espinhaço Setentrional Thrust and Fold Belt (Bittencourt 2014). Using hornblende and plagioclase as a pair, Cruz (2004) estimated temperatures 
between 580 and $745^{\circ} \mathrm{C}$ for the syntectonic metamorphism of the Lagoa Real Intrusive Suite associated with the evolution of the São Timóteo shear zone. Both in the Carrapato shear zone, especially in the rocks of the Lagoa D'anta mine, and in the São Timóteo shear zone, syntectonic plagioclase recrystallization suggests temperature conditions higher than $550^{\circ} \mathrm{C}$ (White 1976; Tullis et al. 1982; Urai et al. 1986; Hirth \& Tullis 1992). The presence of tremolite crowning magnesiohornblende in metabasalt suggests retrometamorphic conditions of greenschist facies late to $\mathrm{D}_{\mathrm{n}+1}$.

At the scale of the mine, brittle structures stored hydrothermal fluids which were responsible for the creation of stockwork structures and veins of calcite, grunerite and magnetite. Specific studies have not been conducted yet in order to determine neither the temperature nor the composition of these fluids. These fractures are of uncertain age and were the main channels for meteoric water circulation during the supergene alteration of the protore, which led to manganese enrichment.

\section{CONCLUSIONS}

From what has been presented in this study, we can conclude the following:

1. the Lagoa D'anta mine is predominated by a collection of compressional structures compatible with four deformational phases, called $\mathrm{D}_{\mathrm{n}-1}, \mathrm{D}_{\mathrm{n}}, \mathrm{D}_{\mathrm{n}+1}$ and $\mathrm{D}_{\mathrm{n}+2}$, which present a ductile structural framework comprising $S_{0} / / S_{n-1}$ and $S_{0} / / S_{n}$ bandings, $S_{n-1}$ and $S_{n}$ schistosity, folds from two generations, as well as stockwork structures and fractures. These structures were responsible for the finite geometry of the manganese protore, whose exploitation is associated with the presence of meteoric water circulation in fractures of uncertain age and supergene $\mathrm{MnO}$ enrichment;

2. deformational structures are the result of a maximum regional tension field oriented WSW-ENE, which, in turn, is associated with collisions between the Amazonian, São Francisco-Congo and Rio de la Plata paleoplates during the Ediacaran. In this sector of the northern portion of the Araçuaí Orogen, this tension field was responsible for the activation of the basement of the Paramirim Aulacogen and for the nucleation of the Carrapato and São Timóteo shear zones during phase $\mathrm{D}_{\mathrm{n}}$, westwards and eastwards from the Lagoa D'anta mine, respectively. The transpression associated with the generation of these structures led to the reactivation of older structures of the basement and to the nucleation of shear zones and folds with NE-SW orientation from phase $\mathrm{D}_{n+1}$. Gradually, folds from phase $\mathrm{D}_{\mathrm{n}+2}$ with general NW-SE orientation developed, which, in this case, was controlled by the maximum regional tensions. The progressive metamorphism associated with the formation of these structures occurred under minimum temperatures associated with conditions of low amphibolite facies with retrometamorphism of greenschist facies.

\section{ACKNOWLEDGMENTS}

The authors would like to express their acknowledgements to the Companhia de Pesquisa de Recursos Minerais (CPRM), to the Companhia Baiana de Pesquisa Mineral (CBPM) and to the Post-Graduation Program of the Universidade Federal da Bahia for their supp ort towards the performed studies, as well as to Conselho Nacional de Desenvolvimento Científico e Tecnológico (CNPq) for the Research Fellowship grant (Processes 307590/2009-7 and 306744/2012-0) offered to Simone C. P. Cruz, through the Universal Call for Projects (Process 473806/2010-0), and for the Master's Degree grant of Jofre O. Borges. In addition, we would also like to express our sincere gratitude to the anonymous reviewers of this manuscript, as well as to the editor, Aroldo Misi.

\section{REFERENCES}

Alkmim, F.F., Pedrosa-Soares, A.C, Noce, C. M., Cruz, S.C.P. 2007. Sobre a Evolução Tectônica do Orógeno Araçuaí-Congo Ocidental. Geonomos, 15: 25-43.

Arcanjo J.B., Marques-Martins A.A., Loureiro H.S.C., Varela P.H.L. 2000. Projeto vale do Paramirim, escala 1:100.000. Programa de Levantamentos Geológicos Básicos do Brasil. CD-ROM.

Babinski M., Pedreira A., Brito-Neves B.B., Van-Schmus W.R. 1999. Contribuição à geocronologia da Chapada Diamantina. In: SBG, 70 Simpósio Nacional de Estudos Tectônicos, Anais, p. 118-121.

Babinski M., Pedrosa-Soares A.C., Trindade R.I.F., Martins M., Noce C.M., Liu D. 2011. Neoproterozoic glacial deposits from the Araçuaí orogen, Brazil: Age, provenance and correlations with the São Francisco craton and West Congo belt. Gondwana Research, 21(2-3):451-465.
Babinski M., Vieira L.C., Trindade R.I.F. 2007. Direct dating of the Sete Lagoas cap carbonate (Bambuí Group, Brazil) and implications for the Neoproterozoic glacial events. Terra Nova, 19:401-406.

Barbosa,J.S.F.\&Sabaté, P.2002. Geological featureand thepaleoproterozoic od four archean crustal segments of the São Francisco Craton, Bahia, Brazil. A syntesis. Anais da Academia Brasileira de Ciências, 2:343-359.

Barbosa J.S.F., Santos-Pinto M., Cruz S.C.P., Souza J.S. 2012. Granitoides. In: Barbosa J.S.F. (coord.). Geologia da Bahia, Pesquisa e Atualização, v. 13. Salvador, CBPM, Série Publicações especiais, p. 327-394.

Barbosa N.S., Teixeira W., Bastos-Leal L.R., Menezes-Leal A.B. 2013. Evolução crustal do setor ocidental do Bloco Arqueano Gavião, Cráton do São Francisco, com base em evidências U-Pb, Sm-Nd e Rb-Sr. Geologia USP, Série Científica, 4:63-88. 
Barbosa O. \& Moutinho da Costa L.A. 1973. Projeto Leste do Tocantins/Oeste do São Francisco; fase IV, II etapa de campo. Rio de Janeiro, CPRM/DNPM/PROSPEC, 8v.

Bastos-Leal L.R.B. 1998. Geocronologia U/Pb (SHRIMP), ${ }^{207} \mathrm{~Pb} /{ }^{206} \mathrm{~Pb}$, $\mathrm{Rb}-\mathrm{Sr}$, Sm-Nd e K-Ar dos Terrenos Granito-Greenstone do Bloco do Gavião: implicações para evolução arqueana e proterozóica do Cráton do São Francisco, Brasil. PhD Thesis, Instituto de Geociências, Universidade de São Paulo, São Paulo, 178 p.

Bastos-Leal L.R.B., Teixeira W., Cunha J.C., Leal A.B.M., Macambira M.J.B., Rosa M.L.S. 2000. Isotopic signatures of paleoproterozoic granitoids of the Gavião block and implications for the evolution of the São Francisco craton, Bahia, Brazil. Revista Brasileira de Geociências, 30:66-69.

Bittencourt C.N. 2014. Petrologia e análise estrutural multiescalar da Formação Serra da Garapa (Grupo Santo Onofre) na porção sul do cinturão de dobramentos e cavalgamentos espinhaço setentrional. Corredor do Paramirim, Caetité, Bahia. Trabalho Final de Graduação, Instituto de Geociências, Universidade Federal da Bahia, Salvador, 118 p.

Borges J.O. 2008. Geologia do Distrito Manganesífero de Urandi-Licínio de Almeida: resultados preliminares. Trabalho Final de Graduação, Instituto de Geociências, Universidade Federal da Bahia, Salvador, 118 p.

Borges J.O. 2012. Geologia e evolução metalogenética do minério de manganês da mina Lagoa D’anta, subdistrito ferro-manganesífero de Caetité-Licínio de Almeida, Bahia. MS Dissertation, Instituto de Geociências, Universidade Federal da Bahia, Salvador, 216 p.

Cordani U.G., Iyer S.S., Taylor P.N., Kawashita K., Sato K., Mcreath I. 1992. Pb-Pb, Rb-Sr, and K-Ar sistematic of the Lagoa Real uranium province (south-central Bahia, Brazil) and the Espinhaço Cycle (ca. 1,5-1.0 Ga). Journal South American Earth Science, 1:33-46.

Cordani U.G., Sato K., Marinho M.M. 1985. The geologic evolution of the ancient granite-greenstone terrane of central-southern Bahia, Brazil. Precambrian Research, 27:187-213.

Cruz S.C.P. 2004. A interação tectônica entre o Aulacógeno do Paramirim e o Orógeno Araçuaí-Oeste Congo. PhD Thesis, Universidade Federal de Ouro Preto, Ouro Preto, 505 p.

Cruz S.C.P. \& Alkmim F. F. 2006. The tectonic interaction between the Paramirim Aulacogen and the Araçuaí Belt, São Francisco Craton region, Easter Brazil. Anais da Academia Brasileira de Ciências, 1:151-173.

Cruz S.C.P., Alkmim F.F., Leite C.M.M., Evangelista H.J. Cunha J.C., Matos E.C., Noce C.M., Marinho M.M. 2007a. Geologia e arcabouço estrutural do Complexo Lagoa Real, Vale do Paramirim, Centro-Oeste da Bahia. Revista Brasileira de Geociências, 37(supl 4):128-146.

Cruz S.C.P., Alkmim F.F., Pedreira A., Teixeira L., Pedrosa-Soares A.C., Gomes L.C.C., Souza J.S., Leal A.B.M. 2012. O Orógeno Araçuaí. In: Barbosa J.S.F., Mascarenhas J.F., Corrêa-Gomes L.C, Domingues J.M.L. (eds.). Geologia da Bahia. Pesquisa e atualização de dados, v. 2. Salvador, CBPM, p. 131-178

Cruz S.C.P., Barbosa J.S.F., Alves E.S., Damasceno G.C., Machado G.S Borges J.O., Gomes A.M., Mesquita L., Pimentel I., Menezes-Leal A.B, Palmeira D.S. 2009. Mapeamento geológico e levantamentos de recursos minerais da olha Caetité (escala 1:100.000). Programa de Levantamentos Geológicos Básicos, Convênio UFBA-CPRM-FAPEX, Salvador, 175 p.

Cruz S.C.P., Barbosa J.S.F., Barbosa A.C., Jesus S.S.G.P., Medeiros E.L.M., Figueiredo B.S., Menezes-Leal A.B., Lopes P., Souza J.S. 2014. Mapa Geológico da Folha Espinosa. PRONAGEO, Convênio UFBA-CPRM-FAPEX

Cruz S.C.P., Dias V.M., Alkmim F.F. 2007b. A interação tectônica embasamento/cobertura em aulacógenos invertidos: um exemplo da Chapada Diamantina Ocidental. Revista Brasileira de Geociências, 37(supl 4):111-127.
Cunha J.C., Barbosa J.S.F., Mascarenhas J.F. 2012. Os greenstone belts. In: Barbosa J.S.F., Mascarenhas J.F., Corrêa-Gomes L.C., Domingues J.M.L. Geologia da Bahia, v. 2. Pesquisa e atualização de dados. Salvador, CBPM, p. 203-326.

Cunningham D. 2005. Active intracontinental transpressional mountain building in the Mongolian Altai: defining a new class of orogen. Earth and Planetary Science Letters, 240:436-444

Cunningham D. 2013. Mountain building processes in intracontinental oblique deformation belts: lessons from the Gobi Corridor, Central Asia. Journal of Structural Geology, 46:255-282.

Dalton de Souza J., Kosin M., Melo R.C., Santos R.A., Teixeira L.R., Sampaio A.R., Guimarães J.T., Vieira Bento R., Borges V.P., Martins A.A.M., Arcanjo J.B., Loureiro H.S.C., Angelim L.A.A. 2003. Mapa Geológico do Estado da Bahia. Escala 1:1.000.000. Salvador, CPRM, 2003.

Danderfer Filho A. 1990. Análise estrutural descritiva e cinemática do Supergrupo Espinhaço na região da Chapada Diamantina (BA). MS Dissertation, Departamento de Geologia, Universidade Federal de Ouro Preto, Ouro Preto, 99p.

Danderfer Filho A. 2000. Geologia sedimentar e evolução tectônica do Espinhaço Setentrional, estado da Bahia. PhD Thesis, Instituto de Geociências, Universidade Federal de Brasília, Brasília, 497 p.

Danderfer Filho A., De Waele B., Pedreira A., Nalini H.A. 2009. New geochronological constraints on the geological evolution of Espinhaço basin within the São Francisco Craton-Brazil. Precambrian Research, 170:116-128.

Delvigne J.E. 1998. Atlas of micromorphology of mineral alteration and weathering. $3^{\text {rd }}$ ed. Orstom Éditions, Canadá, 495 p.

Figueiredo B.S. 2009. Mapeamento geológico e análise estrutural da Sequência Metavulcanossedimentar Urandi, Bahia. Trabalho Final de Graduação, Instituto de Geociências, Universidade Federal da Bahia, Salvador, 135p

Figueiredo B.S., Cruz S.C.P., Ribeiro P.A., Fleck A. 2013. Geologia e arcabouço estrutural da Sequência Metavulcanossedimentar Urandi, Bahia. Brazilian Journal of Geology, 43(2):355-372.

Fleuty M.J. 1964. The descriptions of folds. Proceedings of the Geologists Association, 75(4):461-492.

Fossen H. 2010. Structural Geology. Cambridge University Press, New York, 480 p.

Guadagnin F., Chemale Jr. F., Magalhães A.J.C., Santana A., Dussin I., Takehara L. 2015. Age constraints on crystal-tuff from the Espinhaço Supergroup - insight into the Paleoproterozoic to Mesoproterozoic intracratonic basin cycles of the Congo - São Francisco Craton. Gondwana Research, 7:363-376.

Guimarães J.T., Alkmim F.F., Cruz S.C.P. 2012. Supergrupos Espinhaço e São Francisco. In: Barbosa J.S.F., Mascarenhas J.F., CorrêaGomes L.C., Domingues J.M.L. (eds.). Geologia da Bahia. Pesquisa e atualização de dados, v. 2. Salvador, CBPM, p. 33-86.

Guimarães J.T., Teixeira L.R., Silva M.G., Martins A.A.M., AndradeFilho E.L., Loureiro H.S.C., Arcanjo J.B., Dalton de Souza J., Neves J.P., Mascarenhas J.F., Melo R.C., Bento R.V. 2005. Datações U/Pb em rochas magmáticas intrusivas no Complexo Paramirim e no Rifte Espinhaço: uma contribuição ao estudo da Evolução Geocronológica da Chapada Diamantina. In: SBG/BA-SE, 3o Simpósio do Cráton do São Francisco, Anais de Resumos Expandidos, p. 159-161.

Hirth G. \& Tullis J. 1992. Dislocation creep regimes in quartz aggregates. Journal of Structural Geology, 14(2):145-159.

Jones R., Holdsworth R.E., Clegg P., McCaffrey K., Tavarnelli E. 2004. Inclined transpression. Journal of Structural Geology, 26(8):1531-1548. 
Loureiro H.S.C., Lima E.S., Macedo E.P., Silveira F.V., Bahiense I.C., Arcanjo J.B.A., Moraes-Filho J.C., Neves J.P., Guimarães J.T., Rodrigues L.T., Abram M.B., Santos R.A., Melo R.C. 2010. Geologia e recursos minerais da parte norte do Corredor de Deformação do Paramirim: Projeto Barra-Oliveira dos Brejinhos. Série Arquivos Abertos, v. 33. Salvador, CBPM, 118 p.

Machado G.S. 2008. Geologia da porção sul do Complexo Lagoa Real, Caetité, Bahia. Trabalho final de Graduação, Instituto de Geociências, Universidade Federal da Bahia, Salvador, 90 p.

Machado R. 1977. Geologia e gênese do Depósito de Manganês de Bandarra, Município de Jacaraci, Bahia. MS Dissertation, Instituto de Geociências, Universidade de São Paulo, São Paulo, 109 p.

Machado R. 1983. Geologia do deposito de manganês de Bandarra, Município de Jacaraci, Bahia. Boletim do Instituto de Geociências, USP, 14:65-76.

Martins A.A.M. 2014. Projeto Brumado - Condeúba. Salvador, CPRM. No prelo. Programa Geologia do Brasil - PGB.

Medeiros E.L.M. 2012. Geologia, evolução estrutural e geocronologia do Complexo Santa Isabel na região de Urandi, Bahia. MS Dissertation, Instituto de Geociências, Universidade Federal da Bahia, Salvador, 186p.

Menezes-Leal A.B., Bastos-Leal L.R., Cunha J.C., Teixeira W. 2005. Características geoquímicas dos granitóides transamazônicos no Bloco Gavião, Cráton São Francisco, Bahia, Brasil. Geochimica Brasiliensis, 19:8-21.

Moraes A.C., Martins A.A.M., Sampaio A.R. 1980. Projeto BrumadoCaetité, Relatório Final, $1^{\text {a }}$ fase. v. 1, Convênio DNPM/CPRM. Salvador, CPRM, 463 p.

Moutinho da Costa L.A. \& Inda H.A.V. 1982. O Aulacógeno do Espinhaço. Ciências da Terra, 2:13-18.

Pedrosa-Soares A.C. \& Alkmim F.F. 2011. How many rifting events preceded the development of the Araçuaí-West Congo orogen? Geonomos, 19(2):244-251.

Pedrosa-Soares A.C., Noce C.M., Wiedemann C.M., Pinto C.P. 2001. The Araçuaí-West-Congo Orogen in Brazil: an overview of a confined orogen formed during Gondwanaland assembly. Precambrian Research, 110(1-4):307-323.

Peucat J.J., Mascarenhas J.F., Barbosa J.S.F., de Souza S.L., Marinho M.M., Fanning C.M., Leite C.M.M. 2002. 3.3 Ga SHRIMP U-Pb zircon age of a felsic metavolcanic rock from the Mundo Novo Greenstone belt in the São Francisco Craton, Bahia (NE Brazil). South American Journal of Earth Sciences, 15:363-373.

Pimentel M.M., Machado N., Lobato L.M. 1994. Geocronologia U/Pb de rochas graníticas e gnáissicas da região de Lagoa Real, Bahia, e implicações para a idade da mineralização de urânio. In: SBG, $38^{\circ}$ Congresso Brasileiro de Geologia, Boletim de Resumos Expandidos, p. $389-390$

Portela A.C.P., Marchetto C.L., Meneguesso G., Stein H., Moutinho da Costa L.A., Batista M.B., Mossmann R., Silva W.G. 1976. Projeto Leste de Tocantins/Oeste do Rio São Francisco. Rio de Janeiro, DNPM/ CPRM, 300 p.

Ramsay G. \& Hubber M.I. 1987. The techniques of modern structural Geology: folds and fracture. London, Academic Press, 391 p.
Rocha G.M.F., Souza S.L., Garrido I.A.A. 1998. Distrito manganesífero de Urandi-Licínio de Almeida, Bahia: geologia e potencialidade econômica. Série Arquivos Abertos, v. 12. Salvador, CBPM, 34 p.

Sanderson D.J. \& Machini W.R.D. 1994. Transpression. Journal of Structural Geology, 5:449-458.

Santimano T. \& Riller U. 2012. Revisiting thrusting, reverse faulting and transpression in the southern Sudbury Basin, Ontario. Precambrian Research, 200-203:74-81.

Santos-Pinto M.A.S. 1996. Le recyclage de la croúte continentale archéenne: exemple du bloc du Gavião-Bahia, Brésil. Rennes, Mémoire de Géociences Rennes, 75, 193 p.

Santos-Pinto M.A.S., Peucat J.J., Martin H., Sabaté P. 1998. Recycling of the Archaean continental crust: the case study of the Gavião Block, Bahia, Brazil. Journal of South American Earth Science, 11:487-498.

Sarkarinejad K. \& Azizi A. 2008. Slip partitioning and inclined dextral transpression along the Zagros Thrust System, Iran. Journal of Structural Geology, 30:116-136.

Sarkarinejad K., Partabian A., Faghih A. 2013. Variations in the kinematics of deformation along the Zagros inclined transpression zone, Iran: implications for defining a curved inclined transpression zone. Journal of Structural Geology, 48:126-136.

Souza S.L., Moraes A.M.V., Lopes G.A.C., Cruz M.J.M. 1984. Projeto Caetité. Salvador, CBPM, Convênio SME-CBPM.

Souza S.L., Moraes A.M.V., Lopes G.A.C., Cruz M.J.M. 1990. Projeto Caetité fase II. Salvador, CBPM, Convênio SME-CBPM.

Teixeira L.R. 2000. Projeto Vale do Paramirim. Relatório Temático de Litogeoquímica. Salvador, Convênio CPRM/CBPM, 49 p.

Tikoff B. \& Peterson K. 1998. Physical experiments of transpressional folding. Journal of Structural Geology, 6:661-672.

Tikoff B. \& Teyssier C., 1994. Strain modeling of displacementfield partitioning in transpressional orogens. Journal of Structural Geology, 16:1575-1588.

Tullis J., Snoker A.W., Victoria R.T. 1982. Significance and petrogenesis of mylonitic rocks. Geology, 10:227-230.

Turpin L., Maruèjol P., Cuney M. 1988. U-Pb, Rb-Sr and Sm-Nd chronology of granitic basement, hydrotermal albitites and uranium mineralization, Lagoa Real, South Bahia, Brazil. Contribution to Mineralogy and Petrology, 98:139-147.

Urai J.L., Means W.D., Lister G.S. 1986. Dynamic recrystallisation of minerals. In: Heard H.C. \& Hobbs B.E. (eds.). Mineral and rock deformation: laboratories studies. American Geophysical Union, 36:161-199.

Walker R. \& Jackson J. 2004. Active tectonics and late Cenozoic strain distribution in central and eastern Iran. Tectonics, 23(5):TC5010.

White S.H. 1976. The effects of strain on microstructures, fabrics and deformation mechanisms in quartzits. Philosophical Transactions of the Royal Society of London, A283:69-86.

Wilcox R.E., Harding T.P., Seely D.R. 1985. Basic wrench tectonics. The American of Petroleum Geologists Bulletin, 1:74-96.

Arquivo digital disponível on-line no site www.sbgeo.org.br 